San Jose State University

SJSU ScholarWorks

Master's Projects

Master's Theses and Graduate Research

$5-2019$

\title{
San Jose's Removing and Preventing Illegal Dumping Program (RAPID): An Evaluation of Illegal Dumping in San Jose
}

Rina Laxamana

San Jose State University

Follow this and additional works at: https://scholarworks.sjsu.edu/etd_projects

Part of the Environmental Policy Commons, Other Public Affairs, Public Policy and Public

Administration Commons, Policy Design, Analysis, and Evaluation Commons, Public Administration

Commons, and the Public Policy Commons

\section{Recommended Citation}

Laxamana, Rina, "San Jose's Removing and Preventing Illegal Dumping Program (RAPID): An Evaluation of Illegal Dumping in San Jose" (2019). Master's Projects. 670.

DOI: https://doi.org/10.31979/etd.m5fu-6st9

https://scholarworks.sjsu.edu/etd_projects/670

This Master's Project is brought to you for free and open access by the Master's Theses and Graduate Research at SJSU ScholarWorks. It has been accepted for inclusion in Master's Projects by an authorized administrator of SJSU ScholarWorks. For more information, please contact scholarworks@sjsu.edu. 


\section{San Jose's Removing and Preventing Illegal Dumping Program (RAPID):}

An Evaluation of Illegal Dumping in San Jose

by

Rina Laxamana

A Thesis Quality Research Paper

Submitted in Partial Fulfillment of the

Requirements for the

Masters Degree

in

PUBLIC ADMINISTRATION

Prof. Frances Edwards, Ph.D.

Adviser

The Graduate School

San Jose State University

May, 2019 


\section{Table of Contents}

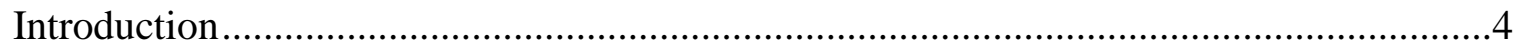

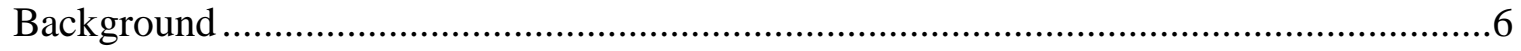

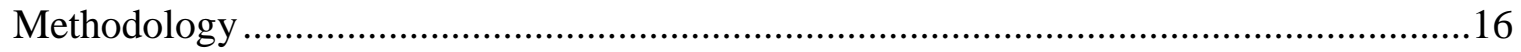

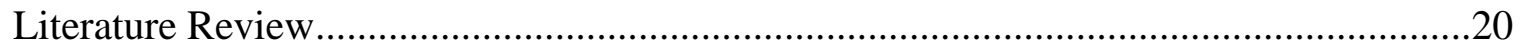

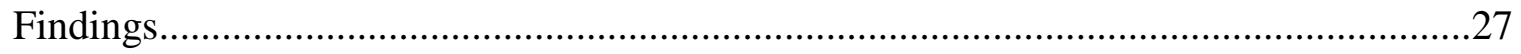

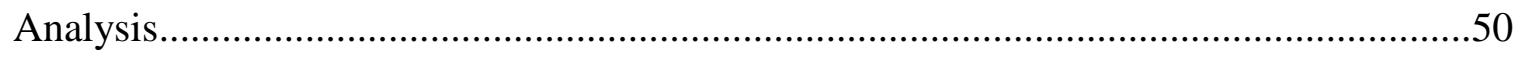

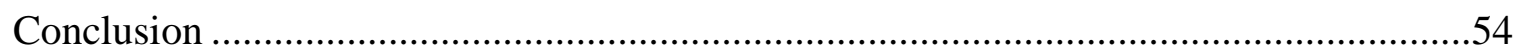

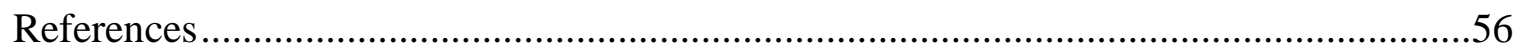

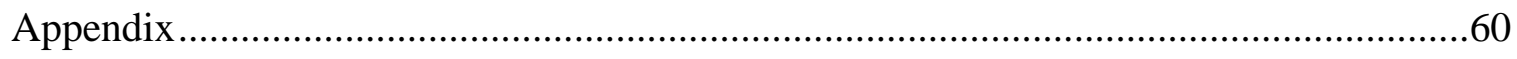




\section{List of Tables and Figures}

Table 1: Illegally Dumped Material July 2016- November 2016 ..................................11

Table 2: Illegally Dumped Material Fiscal Year ......................................................11

Table 3: Outcome Evaluation City of San Jose's Removing and Preventing Illegal Dumping

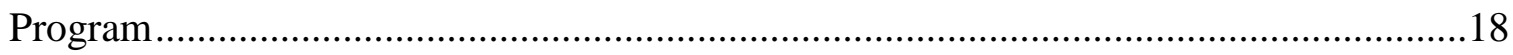

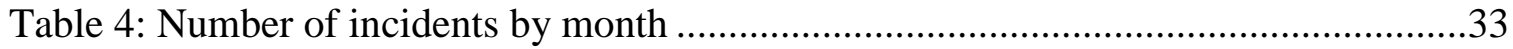

Table 5: Percent change of items picked up, from FY 2016-2017 to FY 2017-2018

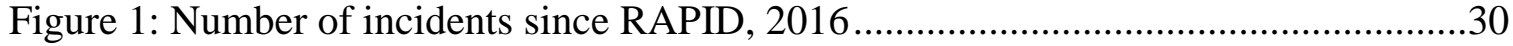

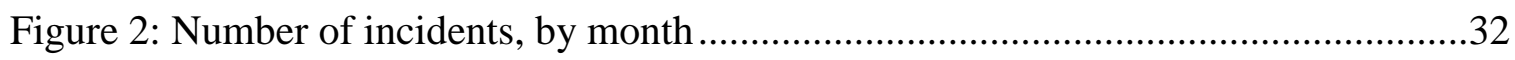

Figure 3: Number of incidents with no items collected .............................................35

Figure 4: Number of incidents compared to no items picked up ...................................37

Figure 5: Number of incidents vs. My San Jose app, 2017 .......................................39

Figure 6: Average clean up time compared to the number of incidents ..........................41

Figure 7: Logarithmic scale of items collected by month and year ...............................43

Figure 8: Linear scale of items collected by month and year ......................................44

Figure 9: Percent of single-family dwellings participated in the Junk Pickup program, FY 2017-

18.

Figure 10: Percent of multi-family dwellings participated in the Junk Pickup program, FY 201718. .48 


\section{INTRODUCTION}

Illegal dumping is a major environmental concern throughout the United States and most countries (Ichinose \& Yamamoto, 2011). Abandoned items such as household material, dumped garbage or construction debris leave odors and contaminants that can threaten community health, impact the environment, and degrade the city's visual appearance (Dabholkar, Muthiyan, Srinivasan, Ravi, Jeon, \& Gao, 2017). To reduce illegal dumping, many cities establish education programs, social-media-based community applications, surveillance camera monitoring, and execute policies with associated penalties and fines (Dabholkar et al., 2017). The City of San Jose is battling an illegal dumping problem and has created the Removing and Preventing Illegal Dumping (RAPID) program to address the challenges. The research question in this study is, is the Removing Preventing Illegal Dumping (RAPID) program effective at mitigating the volume of illegal dumping incidents in San Jose? 


\section{BACKGROUND}

Dumping occurs anywhere such as residential areas or unfrequented mountain paths (Dabholkar et al., 2017). Areas that receive a significant proportion of illegal dumping activity are called hotspots. Litter consists of small amounts of trash, but illegal dumping includes large amounts of garbage that attract additional dumping and criminal activity (City of San Jose, n.d.). The Broken Windows Theory is the idea that if small problems are left unresolved, more significant problems will be created (Kellins \& Wilson, 1982). The theory can be applied to illegal dumping because if items are not cleaned up immediately, offenders interpret the disorder as a signal that no one cares about the neighborhood, therefore, continue to dump (St. Jean, 2007).

In California, laws against illegal dumping can range from an infraction to a misdemeanor that may include fines ranging from $\$ 3,000$ to $\$ 10,000$ and a six-month jail sentence (Title 10 of Crimes against the Public Health and Safety, 1872). In October 2015, the City of San Jose City Council approved a municipal ordinance against acts of illegal dumping on public or private property (Freitas \& Romanow, 2015). Individuals caught dumping can receive a $\$ 2,500$ fine for their first violation and up to $\$ 10,000$ by their third violation (City of San Jose, n.d.).

Regulations regarding how waste is treated, stored or disposed of are becoming more stringent, causing a dramatic increase in the financial cost of legal waste disposal. Waste generators and haulers often respond to regulations by either paying the higher disposal costs, reducing the volume of waste generated, or illegally disposing into the air, water or soil (Hammitt \& Reuter, 1988). In the City of San Jose, illegal haulers are one of the causes of illegal solid waste disposal activities, including dumping into City and private properties. Haulers are 
considered legal when they operate under franchise agreements which regulate solid waste hauling and disposal within the City (Freitas \& Romanow, 2015).

As of 2015, the City of San Jose has conducted studies to determine the extent of both the volume and frequency of its illegal dumping issues. From 2012 to 2015, there was an estimated $75 \%$ increase in illegally dumped items and a 50\% increase of incidents on public property (Freitas \& Romanow, 2015). Previous efforts to combat illegal dumping were reactive and insufficient to respond to the growing problem. For example, the city only cleaned illegally dumped items in public rights-of-way. A lack of centralized coordination or oversight resulted in five separate City departments working on different aspects of the illegal dumping problem (Freitas \& Romanow, 2015). There was also language missing in the San Jose Municipal Code (SJMC) that prohibits illegal dumping and contracting unauthorized haulers to dispose of unwanted items. The City of San Jose needed to establish an effective enforcement program (Freitas \& Romanow, 2015).

During the 2014-2015 fiscal year, one-time funding of $\$ 150,000$ and $\$ 100,000$ from the Community Development Block Grant Fund (CDBG) was budgeted for resolving San Jose's illegal dumping problem (Freitas \& Romanow, 2015). A portion of the funding was used to hire a consultant, R3 Consulting Group, in order to conduct a citywide survey on dumping, and develop recommendations. "Recommendations included improving prevention efforts, improving enforcement efforts, and establishing interdepartmental coordination to provide oversight" (Freitas \& Romanow, 2015). The research also identified six hotspot locations where staff can install deterrent infrastructure, signage and cameras. Funding from CDBG was used for illegal dumping cleanups in impacted neighborhoods (Freitas \& Romanow, 2015). 
The leading sources for illegally dumped materials in San Jose are from multi-family dwellings (MFDs) and single-family dwellings (SFDs), followed by small haulers, large haulers, and the homeless (Freitas \& Romanow, 2015). It was essential to provide a response to complaints of illegal dumping that was timely, convenient and cost-effective to residents in order to encourage proper disposal of large items such as mattresses, furniture, appliances (refrigerators), tires, and other smaller items.

Santa Clara County estimates that about 7,394 homeless individuals are living in the county, with over 4,000 individuals residing in San Jose. Since San Jose is the largest city in the county and the tenth largest in the United States, trash generated from homeless encampments is a severe and ongoing issue (Romanow, 2016). The Housing Department leads the comprehensive program regarding homeless encampments by providing services and housing to individuals, and subsequently removes remaining trash and litter, using volunteer groups and staff. Issues regarding the removal of their personal property, providing for their housing/service needs, and ensuring public safety, require considerable coordination by the Housing Department's Homelessness Response Team (Romanow, 2016).

An interdepartmental team was established to develop recommendations for cleaning and mitigating illegal dumping. The team included the Department of Transportation (DOT); Planning, Building, and Code Enforcement (PBCE); Parks, Recreation, and Neighborhood Services (PRNS); Housing; and the Environmental Services Department (ESD) (Romanow, 2016). In December 2015, an illegal dumping collection pilot program was established to conduct regular hotspot monitoring and cleaning. The program helped determine the most effective and efficient equipment and staff configuration in order to clean dumped items in each hotspot area. Pilot areas were generally located in downtown and east San Jose that were selected 
based on complaint call volume (Romanow, 2016). The pilot program determined that the volume of illegal dumping complaints in a neighborhood was disproportionate with the occurrences in the same area (Romanow, 2016).

In San Jose's analysis of illegal dumping, R3 Consulting Group recommended that additional funding to remove unwanted items from MFD would be the most effective step to address illegal dumping. ESD may have administered illegal dumping program based on the following information:

- The most comprehensive outreach capabilities in order to design, produce and implement an illegal dumping cessation campaign.

- Regulates and administers contracts for residential solid waste service providers.

- Contracts with other organizations for creek cleanups which may impact illegal dumping in creeks.

- Acts as a lead organization to maintain the City of San Jose's compliance with the Stormwater National Pollution Discharge Elimination System Municipal Regional Permit that requires a long-term strategy to manage solid waste (R3 Consulting Group Inc, 2015).

The Adopted Operating Budget in 2016-2017 included funding for the new RAPID [previously called Illegal Dumping Rapid Response Team (IDRRT)] in ESD. One of the goals of the team is to respond to service requests and clean illegally dumped items within approximately five days. The response was necessary because backlog requests from 2014-2015 had over 300 service requests that were over six months old. Frequent dumping areas will also receive proactive cleanups which will significantly remove the quantity of illegally dumped material from City property and public rights-of-way (Romanow \& Rios, 2017). 
Reporting illegal dumping has been streamlined since the launch of My San Jose, mobile, online, and self-help application in July 2017. Residents can report items and send photos directly to the city, including illegal dumping, abandoned vehicles, graffiti, streetlight outage and potholes (Romanow \& Rios, 2017). The app was deployed to assist Mayor Sam Liccardo's Beautify San Jose initiative (BeautifySJ). BeautifySJ aims to engage the community to keep San Jose free from blight and improve quality of life for residents with the support of the My San Jose app (Moradi, 2018).

Service requests to the RAPID team are generated by public complaints via telephone, online or the app. The RAPID team may conduct additional services if incidents are found enroute to a service call. They respond to all reports of materials, not in the public-right-of-way ( $73 \%$ of calls). The immediate right-of-way hazards will continue to be handled by DOT ( $27 \%$ of calls) (Romanow \& Rios, 2017).

The new RAPID realigns budget actions to fund personnel and a new supervisor in ESD in order to concentrate and enhance response to illegal dumping (Romanow \& Rios, 2017). The RAPID program receives funding from AB 939 and the San Jose operating budget in support of BeautifySJ. The Commercial Solid Waste Fee and Landfill Waste Disposal Fee are referred to as AB 939. Fees from AB 939 are a resource for illegal dumping to collect, divert, and recycle solid waste within San Jose city limits, which also includes removing hazardous waste material (City of San Jose Environmental Services Department, 2016). Starting in the fiscal year 2017-2018, San Jose's adopted operating budget invested in the RAPID program by adding four Maintenance Worker II positions. Combating illegal dumping was one of the City of San Jose's key service area priorities in the 2017-2018 adopted operating budget (City of San Jose, 2017). 
From July 5, 2016, through November 16, 2016, the RAPID received 2,503 service requests from the public, averaging about 26 service requests per day. Since the launch of the My San Jose app, the average number of service requests is 56 per business day, which has decreased since 2016 (Lanese, 2018). Table 1 shows a summary of the materials collected between July 2016 and November 2016.

Table 1: Illegally Dumped Material July 2016- November 2016

\begin{tabular}{|l|l|}
\hline \multicolumn{2}{|c|}{ Illegally Dumped Materials Collected by IDRRT } \\
\hline \multicolumn{2}{|c|}{ Item Tyantity } \\
\hline Mattresses & 1,193 \\
\hline Shopping carts & 620 \\
\hline Mixed debris & 320 tons \\
\hline Waste motor oil & 422 gal \\
\hline Paint & 148 gal \\
\hline Human biological waste & 151 gal \\
\hline
\end{tabular}

From July 2017 to October 2017 the RAPID team completed 98\% more assignments compared to the same timeframe from the previous year. Table 2 details the fiscal year comparison based on debris type collected by the RAPID team.

Table 2: Illegally Dumped Material Fiscal Year

\begin{tabular}{|l|l|l|l|l|}
\hline & FY2016-2017 & $\begin{array}{c}\text { July - October } \\
\mathbf{2 0 1 6}\end{array}$ & $\begin{array}{c}\text { July - October } \\
\mathbf{2 0 1 7}\end{array}$ & $\begin{array}{c}\text { Percent } \\
\text { Increase } \\
\mathbf{2 0 1 6} \text { to 2017 }\end{array}$ \\
\hline $\begin{array}{l}\text { Total Sites } \\
\text { Cleaned }\end{array}$ & 7,029 & 2,537 & 4,395 & $73 \%$ \\
\hline Mixed Debris & 2,250 tons & 853 tons & 1,394 tons & $63 \%$ \\
\hline Mattresses & 2,443 & 974 & 1,131 & $16 \%$ \\
\hline Shopping Carts & 1,908 & 578 & 700 & $21 \%$ \\
\hline Waste Motor Oil & $854 \mathrm{gal}$ & $285 \mathrm{gal}$ & $359 \mathrm{gal}$ & $26 \%$ \\
\hline Paint & $320 \mathrm{gal}$ & $107 \mathrm{gal}$ & $995 \mathrm{gal}$ & $830 \%$ \\
\hline $\begin{array}{l}\text { Human Biological } \\
\text { Waste }\end{array}$ & $528 \mathrm{gal}$ & $175 \mathrm{gal}$ & $270 \mathrm{gal}$ & $54 \%$ \\
\hline
\end{tabular}


The Santa Clara County Sheriff Department's Weekend Work Program (WWP) and ESD partnered to supplement staffing for RAPID during the initial program. The program serves as an alternative jail sentence for low-risk offenders (County of Santa Clara, 2018). Following the establishment of RAPID in July 2016, the backlog of calls for illegal dumping response was eliminated and response time decreased. Since adding the maintenance positions in the fiscal year 2017-18, the response time with the new staff has decreased from 11.2 days to 4.1 days in October 2017 despite increased service requests (Romanow, 2017).

Over 160 hotspot locations are monitored based on dumping reoccurrences, and deterrents such as cameras and signage have been installed. Hotspot locations evolve over time, allowing staff to focus their resources on areas that need it the most. Cameras are rotated every three months to different hotspot locations (Romanow \& Rios, 2017). In July 2017, three hotspot locations with cameras installed captured at least one illegal dumping incident. One of the incidents caught a license plate number allowing ESD enforcement staff to issue a citation. Over 200 reflective signs have been purchased that state "No Illegal Dumping" and display the San Jose Municipal Code section for illegal dumping, and the fine amount (Romanow \& Rios, 2017).

San Jose residents are encouraged to dispose of items through the ESD's legally administered Unlimited Junk Pickup program. SFDs and MFDs can have large items picked up curbside by their recycling company by following four steps. First, review the list of acceptable junk items (Appendix A). Second, determine which residential recycling company services the address by using an interactive map. Third, call the recycling company to schedule an appointment and list of items for pick-up. Fourth, set the items on the curb or adjacent to the recycling bin 24 hours before the scheduled appointment (City of San Jose, n.d.). Starting from July 2017, the program shifted from a pay-per-appointment model to no-additional costs 
(supported by garbage and recycling rates) (Romanow \& Rios, 2017). The program expects to reduce illegal dumping because it is convenient, unlimited and no additional costs to residents with trash and recycle services. There continues to be a high annual participation rate from MFDs (Romanow, 2017). California Waste Solutions and Green Team of San Jose are the primary haulers in the Junk Pickup program.

The City of San Jose has partnered with other organizations to provide options for legally disposing of waste. San Jose State University (SJSU) and ESD collaborated to help prevent illegal dumping around the university communities. The Move Out Swap or Drop event targeted off-campus students to use proper disposal and reuse of items. Unlimited large item collection was administered by ESD (Romanow, 2017). Event participation increased by $35 \%$ from May 2016 to May 2017 with 25\% more material collected. Educational outreach has been incorporated describing proper waste disposal methods for specific items that can be used outside the event. Alternative programs are essential for diverting waste that would have potentially been illegally dumped (Romanow, 2017).

The County of Santa Clara Recycling and Waste Reduction Division administers the Household Hazardous Waste Program (HHW) funded by participating cities and the County of Santa Clara. The program allows residents to schedule an appointment to drop off items such as batteries, paint, household cleaners and propane tanks (County of Santa Clara, 2018). There are three permanent drop-off sites in Santa Clara County available for residents and businesses. From the drop-off site, items are sorted, packed and shipped to one of 20 facilities (Noguchi, 2016).

Outreach campaigns for available programs are necessary to help combat illegal dumping (R3 Consulting Group Inc, 2015). Before the RAPID program, there was minimal education and 
few outreach campaigns to address illegal dumping or use the available public services. Unlike other waste management programs, RAPID primarily focuses on providing services and solutions to address the illegal dumping problem. The programs' outreach efforts aim to give residents options for proper waste disposal using available resources to reduce reliance on the RAPID program. This research examines will look at San Jose's RAPID program, and will help ESD analyze their approach to illegal dumping (County of Santa Clara, 2018). 


\section{METHODOLOGY}

The methodology used to evaluate the data was an outcome analysis categorized by theoretical goals, program goals, program functions, proximate indicators, program measures and program outcomes (Sylvia \& Sylvia, 2012). The researcher collected historical illegal dumping data from R3 Consulting Group and the City of San Jose's Environmental Services Department. The outcome analysis determined the strengths and weaknesses of the Removing Preventing Illegal Dumping (RAPID) program and recommendations to achieve the program goals. Statistical analysis was used to calculate the number of complaints, total number, and type of items collected before and after the program was implemented, and impacts of cleanup response time. Graphs, tables, and charts were used to benchmark the impacts of the program, such as changes in funding, staff, and availability of other programs. The timeframe of this study was from July 2013 to December 2018.

The first program goal was to reduce illegal dumping by streamlining public complaints to one program. Before the RAPID program, the City of San Jose lacked a centralized administrator to organize complaints and collect information. The goals were evaluated by comparing the number of illegal dumping complaints before and after the program was implemented, as well as changes since the launch of the My San Jose app. A dedicated team allows the city to monitor dumping hotspots, and track patterns based on geographic location. The team was also responsible for collecting data specific to illegal dumping, such as item category, item count after it was cleaned up, and provided input on possible enforcement strategies.

The second goal was to prevent repeat dumping incidents by providing reasonable cleanup response times. This section of the research analyzed the staff's cleanup efficiency. The 
program function increased funding to hire staff that responds explicitly to illegal dumping complaints and removed items immediately. The complaint response process is as follows:

- First, public complaints are received via telephone, website, or My San Jose app.

- Second, the Department of Transportation organizes public complaints and collects information specific to illegal dumping requests.

- Third, the Department of Transportation assigns illegal dumping inquiries to the RAPID program.

The indicators include the time and date the complaint was received, and date that cleanup was completed. The anticipated outcome is that streamlining complaints and decreased cleanup response time will reduce the frequency of illegal dumping incidents.

The third program goal was to prevent illegal dumping by working with other programs to promote legal waste disposal. The RAPID program indicates whether the legal disposal programs, such as Unlimited Junk Pickup or the Household Hazardous Waste programs, are reaching their target audience. Since the RAPID program was launched, outreach for the Junk Pickup Program increased and developed from pay-per-item to unlimited. Changes in the Junk Pickup Program may have an impact on the type of items RAPID collects. Program indicators organized illegally dumped items into six categories, and a total count was collected after each cleanup was complete. Program measures will show whether there are changes in the category of items dumped, and determine whether they are covered by other legal disposal programs supported by any local government agencies.

The table below details the outcome evaluation for the research relating to the RAPID program. 
Table 3: Outcome Evaluation

City of San Jose's Removing and Preventing Illegal Dumping Program

\begin{tabular}{|c|c|c|c|c|}
\hline $\begin{array}{l}\text { Theoretical } \\
\text { Goals }\end{array}$ & $\begin{array}{l}\text { Program } \\
\text { Goals }\end{array}$ & $\begin{array}{l}\text { Program } \\
\text { Functions }\end{array}$ & $\begin{array}{l}\text { Proximate } \\
\text { Indicators }\end{array}$ & $\begin{array}{l}\text { Program } \\
\text { Measure }\end{array}$ \\
\hline $\begin{array}{l}\mathrm{T}_{1} \text { : Reduce } \\
\text { and prevent } \\
\text { illegal } \\
\text { dumping in } \\
\text { the City of } \\
\text { San Jose }\end{array}$ & $\begin{array}{l}\mathrm{G}_{1} \text { : } \\
\text { Streamline } \\
\text { how illegally } \\
\text { dumped items } \\
\text { are reported } \\
\text { by the public } \\
\left(\mathrm{T}_{1}\right) \\
\mathrm{G}_{2} \text { : Decrease } \\
\text { cleanup } \\
\text { response time } \\
\text { to prevent } \\
\text { repeated } \\
\left.\text { incidents ( } \mathrm{T}_{1}\right) \\
\\
\mathrm{G}_{3} \text { : Prevent } \\
\text { incidents by } \\
\text { working with } \\
\text { other } \\
\text { organizations } \\
\text { to promote } \\
\text { waste disposal } \\
\left.\text { programs ( } \mathrm{T}_{1}\right)\end{array}$ & $\begin{array}{l}F_{1} \text { : } \\
\text { Introduction } \\
\text { of the My } \\
\text { San Jose } \\
\text { app }\left(\mathrm{G}_{1} ; \mathrm{G}_{2}\right) \\
\mathrm{F}_{2} \text { : } \\
\text { Expansion } \\
\text { of the } \\
\text { Unlimited } \\
\text { Junk Pickup } \\
\text { Program } \\
\left(\mathrm{G}_{3}\right) \\
\mathrm{F}_{3} \text { : Funding } \\
\text { for staff } \\
\text { dedicated to } \\
\text { responding } \\
\text { to } \\
\text { complaints } \\
\text { and clean up } \\
\text { reported } \\
\text { items } \\
\text { immediately } \\
\left.\text { ( } \mathrm{G}_{2}\right)\end{array}$ & $\begin{array}{l}\mathrm{I}_{1}: \text { Number of } \\
\text { illegal } \\
\text { dumping } \\
\text { complaints } \\
\left(\mathrm{F}_{1}\right) \\
\mathrm{I}_{2}: \text { Time and } \\
\text { date of } \\
\text { complaint } \\
\text { received and } \\
\text { cleanup } \\
\text { response time } \\
\left(\mathrm{F}_{1} ; \mathrm{F}_{3}\right) \\
\mathrm{I}_{3}: \text { Category } \\
\text { and amount of } \\
\text { illegally } \\
\text { dumped items } \\
\text { picked up }\left(\mathrm{F}_{2}\right) \\
\\
\mathrm{I}_{4} \text { : Provide } \\
\text { legal disposal } \\
\text { programs and } \\
\text { outreach }\left(\mathrm{F}_{3}\right)\end{array}$ & $\begin{array}{l}\mathrm{M}_{1} \text { : Compare } \\
\text { annual change in } \\
\text { illegal dumping } \\
\text { complaints ( } \mathrm{I}_{1} \text { ) } \\
\mathrm{M}_{2} \text { : Average of } \\
\text { date and time } \\
\text { complaint was } \\
\text { assigned } \\
\text { compared to } \\
\text { cleanup } \\
\left.\text { completed ( } \mathrm{I}_{2}\right) \\
\mathrm{M}_{3} \text { : Changes in } \\
\text { the amount and } \\
\text { type of illegally } \\
\text { dumped items } \\
\text { ( } \mathrm{I}_{3}, \mathrm{I}_{4} \text { ) }\end{array}$ \\
\hline
\end{tabular}




\section{LITERATURE REVIEW}

Illegal dumping is the act of disposing of items on public or private land or water without approval from an authorized agency (United States Environmental Protection Agency [EPA], 2016). Illegally dumped items include household trash and construction debris, as well as hardto-recycle items such as appliances, electronics, tires, and furniture (Ichinose \& Yamamoto, 2011). There are environmental and health hazards associated with illegal dumping, especially if the material contains hazardous chemicals or asbestos (US Environmental Protection Agency, 2016). Limitations in municipal waste management services (Viazanco, 2017) and social factors are linked to acts of illegal dumping (Brandt, 2017). Illegal dumping is an international issue with many government agencies analyzing different solutions. This literature review considers the causes of illegal dumping, environmental impacts, and current programs and policies applied to address the problem.

Illegal dumping is an ongoing, highly visible problem, and is considered an environmental crime in most countries. Dumped items are frequently found in the same locations, called hotspots, including roadways, creeks, unsecured properties, or abandoned lots converted into a dumpsite (Onifade \& Nwabotu, 2014). Activity generally occurs at night or early in the morning to avoid getting caught (Douglas, 1992). Illegally dumped items often reduce property values, diminish aesthetic values of the environment, and deplete community pride (Onifade \& Nwabotu, 2014).

Illegal dumping degrades the environment and can be a source of concentrations of heavy metals, hydrocarbons, nitrogen, and volatile organic compounds (Glanville \& Chang, 2015). Items left over some time can corrode and leach chemicals that can contaminate soil and groundwater (Viazonko, 2017). Research from Poland analyzed soil quality based on proximity 
to an illegal dumpsite. Certain types of soils are capable of sequestering minerals and heavy metals. The study found high concentrations of metals directly below the dumped items (Bartkowiak, Lemanowicz, \& SiwikZiomek, 2016). Humans and wildlife can experience adverse effects when exposed to contaminants caused by illegal dumping (Brandt, 2017).

Social factors that influence illegal dumping include population density, income levels, and mixed land use (Stark, 1987). Dumping rates are higher in dense populations. A study in Romania found that villages with higher population density experienced more dumpsites (Mihai, Apostol, Ghiurca, Lamasanu \& Alexandru, 2012). Research has found that dense populations are in areas that include a high percentage of renters. High renter turnover rates result in limited time to properly dispose of unwanted items while moving (Wright, Smith \& Tull, 2018). Absentee property owners combined with renters who are less invested in the community make illegal dumping more prevalent (Douglas, 1992).

Income levels prove to correlate with illegal dumpsites. There is little research on the subject of homeless and the volume of waste they generate, but there is a correlation between illegal dumping and socioeconomic status (White, 2013). The relation between income and waste generation is highly studied in the field of waste management (Liu, Kong, Gonzalez, 2017). A study in Kentucky observed an increase of affluent urban populations who were moving to rural areas to construct large homes in areas that were previously farmland. Consequently, low-income residents relocated from farmlands into economically depressed urban conditions, causing communities to ignore illegal dumping (Viazanco, 2017). Disposal fees also have a higher financial burden for low-income households compared to high-income (Matsumoto \& Takeuchi, 2011). A study in England concluded that the higher the per capita income of a district, the less likely the residents were to engage in illegal dumping. The results are due to the following: 
- Households with higher income are more likely to be educated with fewer chances to break the law

- A stronger environmental protection awareness and purchasing power to pay for waste service

- Poverty generates crime, including crimes associated with waste (Liu et al., 2017).

The United States is the highest producer of solid waste per capita in the world (Onifade \& Nwabotu, 2014) and illegal dumping is prevalent in many communities throughout the country (Ichinose \& Yamamoto, 2011). Dealing with hotspots and illegal dumpsites takes time, money, and resources from municipalities, communities, and individuals (Fotelink, 2001). Many countries are beginning to reexamine regulations associated with illegal dumping, implementing stringent laws and penalties (Ichinose \& Yamamoto, 2011). Since refuse is collected at the municipal level, solid waste management policies and programs strongly influence the community’s behavior towards illegal dumping (Viazanco, 2017). Techniques to deter illegal dumping include access to services, increased fines and penalties, education, and technological support (Viazanco, 2017).

In Queensland, Australia, an estimated 20,666 tons of illegally dumped waste is disposed of each year, costing local government $\$ 10$ million for disposal (Dept. of Environment and Heritage Protection Queensland, 2014). Solid waste remediation comes at a high cost and can consume up to $30 \%$ of some local government budgets in the US (Glanville \& Chang, 2015). Volunteers commonly clean illegal dumpsites with related legal disposal fees funded by private donations, or by municipalities’ general funds (Nestor Resources, Inc., 2014).

There are several reasons for illegal dumping, but one of the main motivations is to avoid a disposal fee (Osuntokun, 1999). A study in Korea correlated illegal dumping to the 
introduction of unit pricing of solid waste. The study recommended that authorities use caution when increasing unit prices (Kim, Chang, \& Kelleher, 2008). Waste management facilities play an essential role in managing the supply of waste generated in an area. Shortages of these facilities influence illegal dumping because the cost of proper waste disposal will increase (Ichinose \& Yamamoto, 2011).

Charitable organizations also experience impacts of illegal dumping. Donation centers provide a legal collection point to discard unwanted household goods. These sites become hotspots for illegal dumping, especially when the store is closed, because well-intentioned donors will leave items at the front of the building. The organization sells reusable donations to fund its programs. However, items that are unfit for reuse must be disposed of at the landfill, and then the organization pays the cost (National Association of Charitable Recycling Organisations, 2013). The Salvation Army in Australia spends about $\$ 2$ million per year to dispose of waste, diverting funds from charitable programs (Wright, Smith, Tull, 2018).

Illegal dumping is influenced by access to curbside trash and recycling collection systems and drop-off stations managed by local municipalities (Nestor Resources, Inc., 2014). Municipalities that offer curbside collection saw a $49 \%$ recycling rate versus $25 \%$ for drop-off only (Schultz, Oskamp, \& Mainieri, 1995). A study in Lansing, Michigan showed that residents still use drop-off recycling sites to dispose of items not accepted at the curb (Sidique et al., 2010). If waste services are fragmented or unavailable, illegal dumping is the method of choice to discard unwanted items (Viazanco, 2017). Public organizations are developing more recycling and waste reduction programs in response to increased disposal costs and illegal dumping (Porter, 2002). These programs are designed to target dumping before it enters the environment (Willis, Maureaud, Wilcox, \& Hardesty, 2018). 
Maine passed the Covered Device Recycling Act (CDRA) in 2010 banning e-waste from landfills (Pennsylvania Resource Council, 2017). The law holds manufacturers and retailers responsible for recycling costs based on the extended producer responsibility (EPR) law. In the first three years, over 6 million kg of e-waste was recycled. However, it was not as successful as anticipated due to manufacturers restricting returns to products sold within two years of the current date (Pennsylvania Resource Council, 2017). It is essential that the federal government create a regulatory framework integrating industry with collection system challenges (Kahhat et al., 2008).

Penalties and fine structures can deter illegal dumping. The Japanese government has strengthened penalties related to illegal dumpings, such as increasing prison sentences. The research determined that penalties do deter illegal dumping (Ichinose \& Yamamoto, 2011). On the other hand, if fines are lower than the cost of proper disposal, dumpers are likely to take the risk (Nestor Resources, Inc., 2014). Penalties and fines can be inconsistent depending on jurisdiction, and it is necessary to enforce laws on illegal dumpers with "tangible proof, beyond a reasonable doubt" (Nestor Resources, Inc., 2014).

Education and outreach campaigns can assist in reducing illegal dumping, particularly when integrated with resources such as waste management services. For example, research within 40 local councils in Australia found that investments in outreach programs combined with waste management services are associated with a higher reduction of waste compared to policy investments (Willis et al., 2018). Education programs enable environmental awareness and influence community behaviors (Willis et al., 2018).

Technological applications such as geographic mapping monitor illegal dump sites, providing informational support to improve management outcomes. There are geographical 
patterns associated with illegal dumping influenced by many factors (Glanville \& Chang, 2015). Data from monitoring is cost-effective because agencies can rely less on on-the-ground surveys. In New Jersey, geographic and reporting systems were created to engage residents to report illegal dumping through an application or hotline. These techniques have reduced the time and resources spent to identify dump sites by local officials (Viazanco, 2017). 


\section{FINDINGS}

This section provides tables and graphs combining raw data received from R3 Consulting Group and the City of San Jose's ESD. The data from July 2013 to February 2015 was collected by R3 Consulting Group and the data from July 2016 to December 2018 was collected by ESD. The data analyzing the Junk Pickup program was also retrieved from ESD which was information reported from the haulers, California Waste Solutions and Green Team of San Jose. There is missing data between March 2015 to June 2016 because it was a period when R3 Consulting completed their study and before ESD launched the RAPID program. The tables and charts will display the timeframe by either fiscal year (FY) or calendar year.

The number of incidents is defined as the number of illegal dumping complaints at a specific address or geographic location that a RAPID staff member has physically inspected or responded. The Department of Transportation's role is to collect incoming illegal dumping complaints from the My San Jose app, dispatch phone number, or emails. They will then organize complaints by address and compile duplicate complaints into one work order or "incident." Each incident includes an identification number, date and time assigned, date and time completed, geographic coordinates, and item count based on category. The incident assigned is determined by the date and time the Department of Transportation has sent complaint information to the RAPID team. The date and time completed occurs after the RAPID team has assessed the complaint and removed the items. Geographic coordinates provide an accurate location of the incident.

Reported items were recorded by RAPID into 19 different categories (biological waste, construction debris, couch, electronic waste, garbage, general debris, hazardous waste, mattress, other appliances, other electronic waste, other furniture, paint, refrigerator, shopping cart, tire, 
TV set, universal waste, washer/dryer, and yard waste). Items collected within the 19 categories were condensed into the following seven categories:

- Appliances

- Construction material and yard waste

- Furniture

- Garbage

- Hazardous material (hazmat)

- Tires

- Mattresses

R3 Consulting Group collected incident data by month, day and year, and categorized each complaint into ten items (alleys, appliances, furniture, garbage, glass, hazardous material, litter, other, tires and yard waste). Each incident had a list of notes detailing the number and type of items removed documented under "descr_work." In order to keep the data consistent, the researcher read each item under "descr_work" and organized the number of items removed into the same seven categories as RAPID, from July 2013 through May 2014. 
Figure 1 displays the number of illegal dumping incidents since the RAPID program was established. There were 28,462 total incidents between July 2016 and December 2018. The data shows an increase of illegal dumping incidents since the program was launched. From July 2016 compared to July 2018, the number of incidents received by RAPID has tripled. Many factors contribute to the increase in illegal dumping reports. January 2017 demonstrates the first signs of a steady but gradual increase of illegal dumping reports since the program began. In August 2017, there was a $90 \%$ average increase of reports compared to the previous three months. The month of August also indicates higher rates of dumping in 2016 and 2017. August 2018 had 5\% fewer incidents compared to July 2018. Incident patterns since RAPID was launched can be analyzed with previous years detailed in Figure 2. 
Figure 1: Number of incidents since RAPID, 2016

Number of Incidents vs. Date

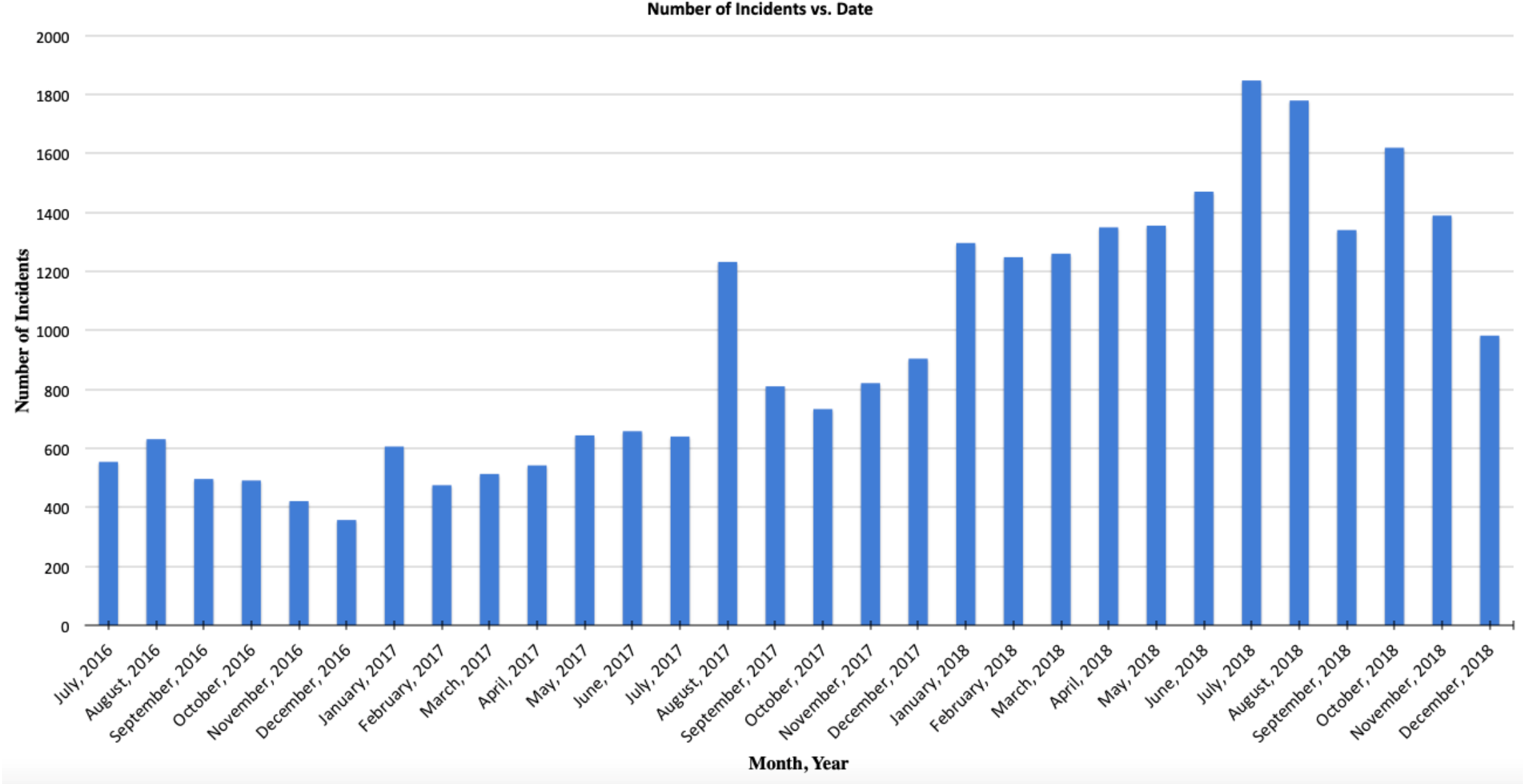


Figure 2 compares the number of incidents each month starting from FY 2013-14, FY 2014-February 2015, FY 2016-17, and FY 17-December 2018. In the earlier years, FY 2013-14, the number of illegal dumping complaints stayed below 500 reports. There was about a $30 \%$ increase in incidents from FY 2013-14 to FY 2014-15. However, from July to February in FY 2014-15 compared to July to February in FY 2016-17 (when RAPID started), there was about a $10 \%$ average increase in the number of incidents. Significant changes occurred in FY 2017-18 where the average number of total incidents increased by about 95\% from FY 2016-17. From July to December 2018 , the number of incidents increased by about $12 \%$ compared to the previous six months. Seasonal patterns are also a contributing factor regarding the frequency of dumping reports which is explained in Table 4. 
Figure 2: Number of incidents, by month

Number of Incidents by Month

| 2013-2014 $\mid$ 2014-2015 $=2016-2017=2017-2018=2018$

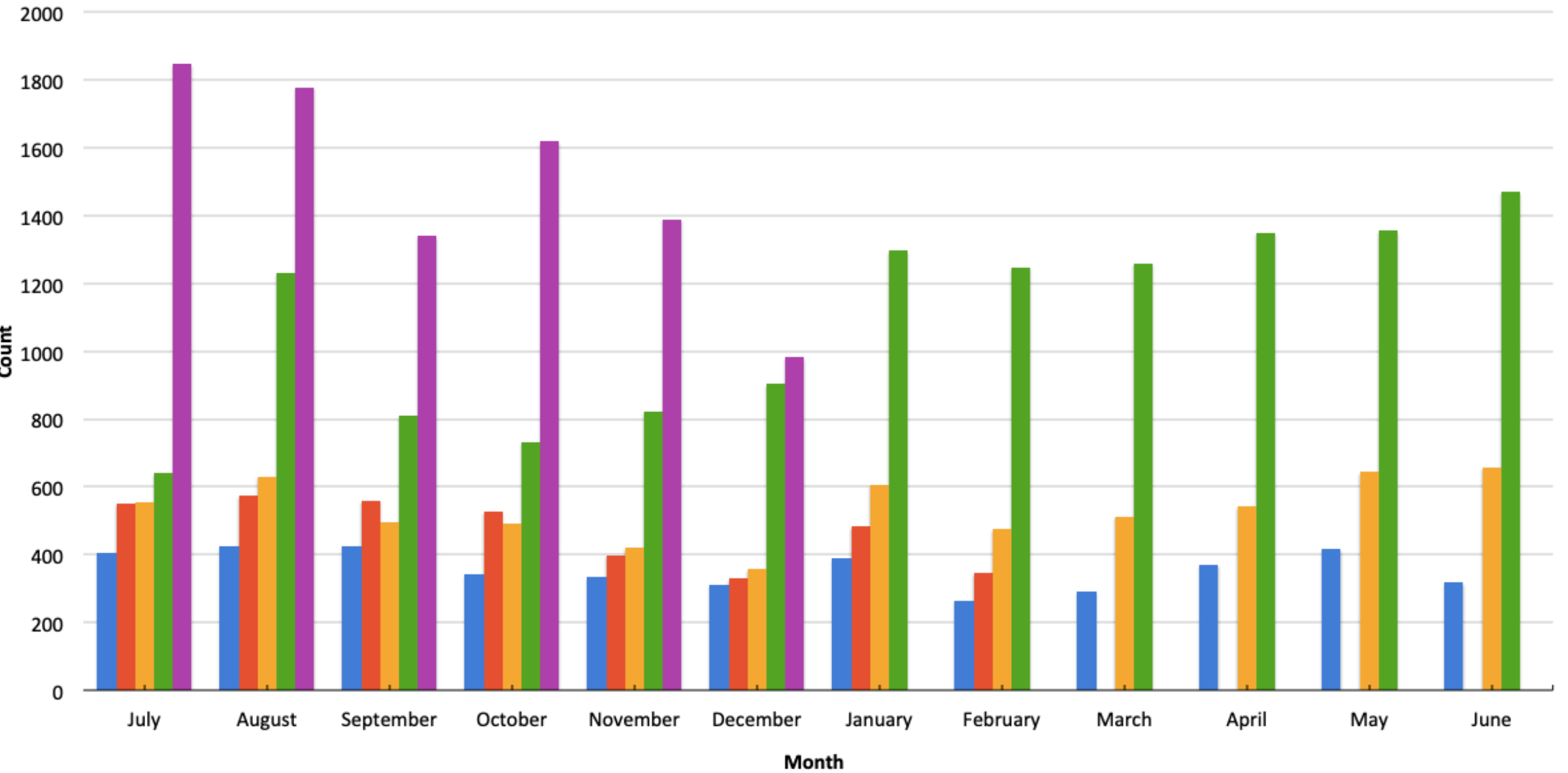


Table 4 shows that the average number of dumping incidents was higher in the summer months (July and August) compared to all the other months, and this was a continuous pattern in overall years. December was also had the lowest number of incidents among each year. Illegal dumping incidents have consistently increased each year with large increases in 2017 and 2018.

Table 4: Number of incidents by month

\begin{tabular}{|l|r|r|r|r|r|r|}
\hline \multicolumn{1}{|c|}{} & \multicolumn{1}{|l|}{ 2013-2014 } & $2014-2015$ & $2016-2017$ & $2017-2018$ & 2018 & Average \\
\hline July & 405 & 551 & 554 & 640 & 1847 & $\mathbf{7 9 9 . 4}$ \\
\hline August & 426 & 575 & 631 & 1232 & 1779 & $\mathbf{9 2 8 . 6}$ \\
\hline September & 426 & 560 & 496 & 810 & 1340 & $\mathbf{7 2 6 . 4}$ \\
\hline October & 341 & 528 & 491 & 733 & 1619 & $\mathbf{7 4 2 . 4}$ \\
\hline November & 333 & 399 & 421 & 821 & 1389 & $\mathbf{6 7 2 . 6}$ \\
\hline December & 310 & 329 & 357 & 904 & 982 & $\mathbf{5 7 6 . 4}$ \\
\hline January & 388 & 483 & 606 & 1296 & & $\mathbf{6 9 3 . 2 5}$ \\
\hline February & 264 & 346 & 475 & 1248 & & $\mathbf{5 8 3 . 2 5}$ \\
\hline March & 292 & & 513 & 1260 & & $\mathbf{6 8 8 . 3 3 3 3 3 3 3}$ \\
\hline April & 370 & & 542 & 1349 & & $\mathbf{7 5 3 . 6 6 6 6 6 6 7}$ \\
\hline May & 417 & & 644 & 1355 & & $\mathbf{8 0 5 . 3 3 3 3 3 3 3}$ \\
\hline June & 317 & & 658 & 1470 & & $\mathbf{8 1 5}$ \\
\hline
\end{tabular}


Figure 3 shows the number of incidents with no items collected when staff went to the site. About 9,647 or $34 \%$ of the incidents resulted in no items picked up or found at the reported incident location from July 2016 to December 2018. There was a steady increase in complaints with no items found starting in December 2017. There was a 319\% average increase of incidents with no items found reported from January to December 2018 compared to the previous year in January to December 2017. 
Figure 3: Number of incidents with no items collected

Number of incidents with no items found

1250

1000

750

苔

500

250

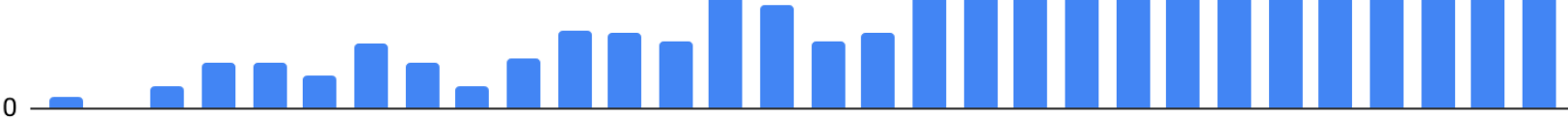

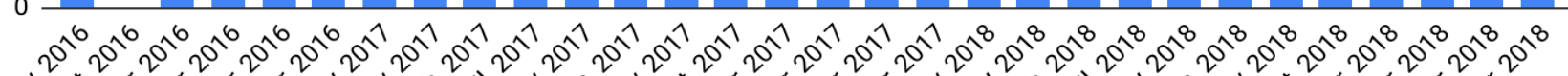
30 "

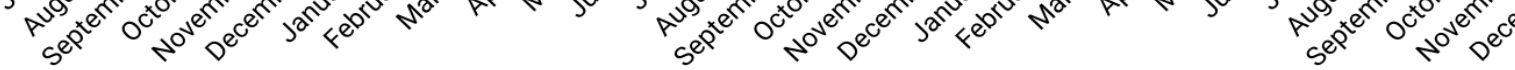

Month/Year 
Figure 4 compares the total number of incidents since the RAPID program was established with the number of incidents with no items found. Although August 2016 had the highest number of incidents in the entire calendar year at 631, it had the lowest number of incidents with no items found. August 2018 continues to have the highest number of illegal dumping incidents compared to 2016, 2017 and 2018. August also had the highest number of incidents with no items found in 2017 and 2018 compared to the other months in the same year. About 25\% of all incidents in August 2017 had no items found, and about $61 \%$ of August 2018 of the total number of incidents had no items found. In 2018, 45\% of all incidents had no items collected, which is significantly higher compared to $21 \%$ in 2017 and $11 \%$ in 2016. 
Figure 4: Number of incidents compared to no items picked up

Number of incidents vs. no items picked up

3500

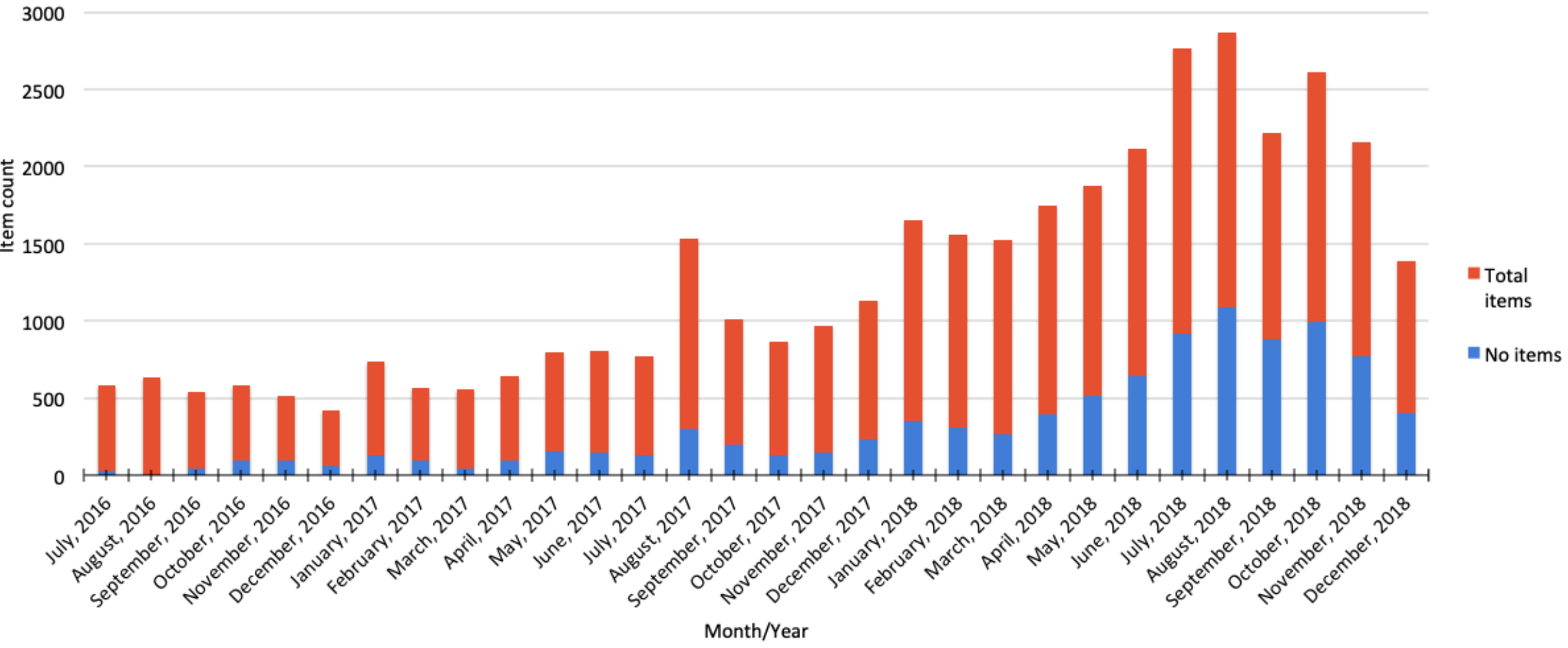


Figure 5 compares the number of incidents with the number of requests since the launch of the My San Jose app. The service request count was collected from research by Moradi (2018). There were about 168 or $14 \%$ more illegal dumping requests from the app compared to the number of incidents the RAPID team was able to respond to in August 2017. By November 2017, the number of complaints received from the app and incident response began to stabilize with a difference of 29 requests to incidents. By January 2018, RAPID responded to more complaints than what was reported by the app. 
Figure 5: Number of incidents vs. My San Jose app, 2017

Incidents Compared to My San Jose App Requests

2000

1800

1600

1400

1200

1000

800

600

400

200

0

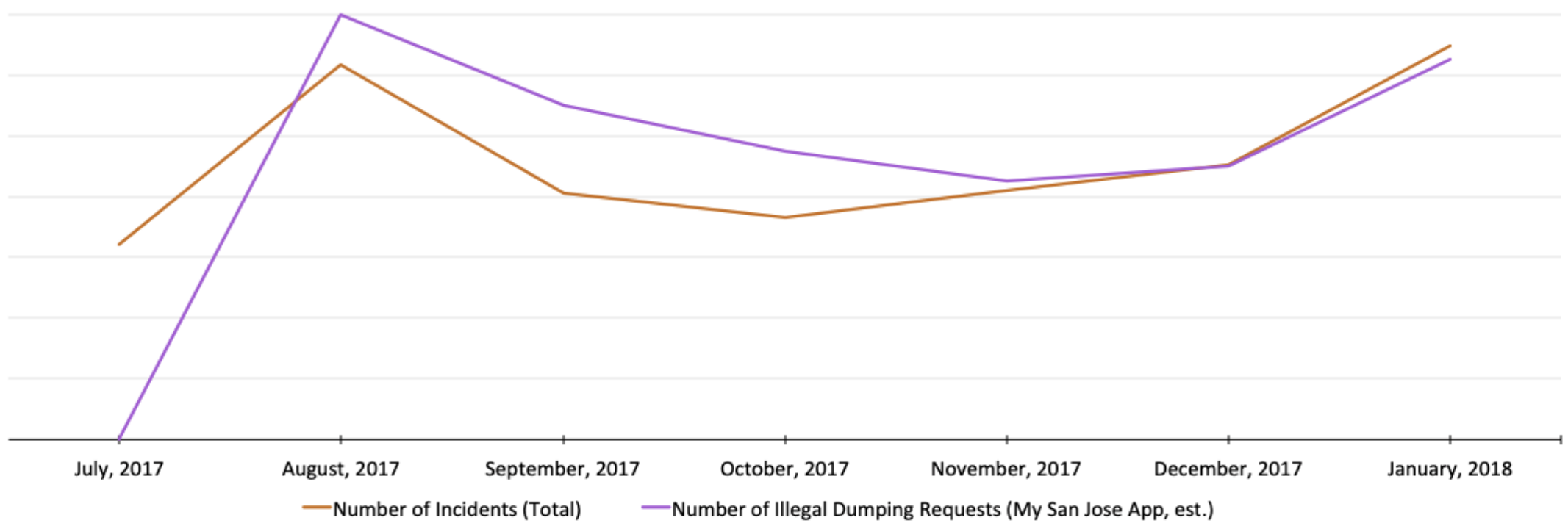


Figure 6 illustrates the response time from when RAPID receives an incident and completes clean up compared to the number of incidents received by the month. In 2016, the total average incident response time was 783 hours. The last six months of 2016 compared to the first six months of 2017 demonstrated a $76 \%$ increase in the total average response time for all incidents. In 2018, the total average response time decreased by $25 \%$ compared to the year before. By January 2018, as the number of incidents continues to increase, the average response time decreases. The average time it took to respond to one incident from July to December 2016 was 130 hours or five days and 9.6 hours. The average response time for each incident from January to December 2017 was 184 hours or seven days and about16 hours. The average time per incident between January and December 2018 was five days and 18 hours. 
Figure 6: Average clean up time compared to the number of incidents

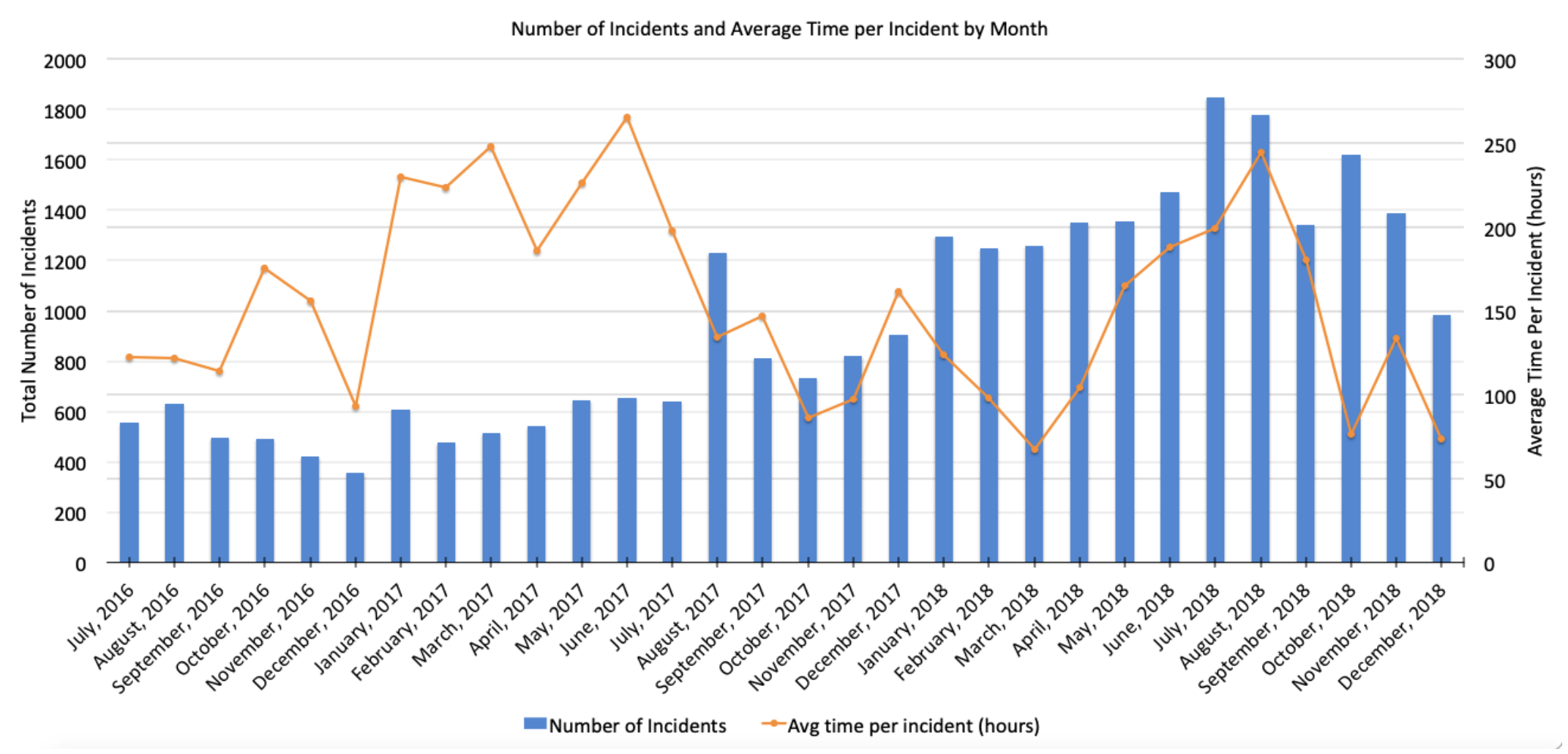


Figures 7 and 8 show the number of items collected by category for each month before and after the RAPID program began. The researcher estimated the item count for each category between July 2013 and June 2014 based on the details written on the work description. The logarithmic scale will help show the broad range of items picked up from each category. From July 2013 to May 2014, the maximum number of hazmat picked up was 22 and a minimum of one with an average of 7 . After June 2016, the monthly average number of hazmat increased to 354, showing hazmat as the outlier. The following lists the average monthly items picked up since the RAPID program began:

- $\quad$ Garbage with 1,316

- Furniture with 412

- Other than hazmat, third was construction material/yard waste with 342

- $\quad$ Mattresses with 288

- Appliances with 150

- $\quad$ Tires with 96 
Figure 7: Logarithmic scale of items collected by month and year

\section{Item Count Types by Date - Logarithmic Scale}

-Appliances

10000

000

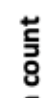

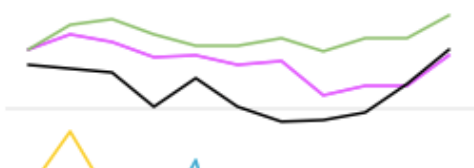

10
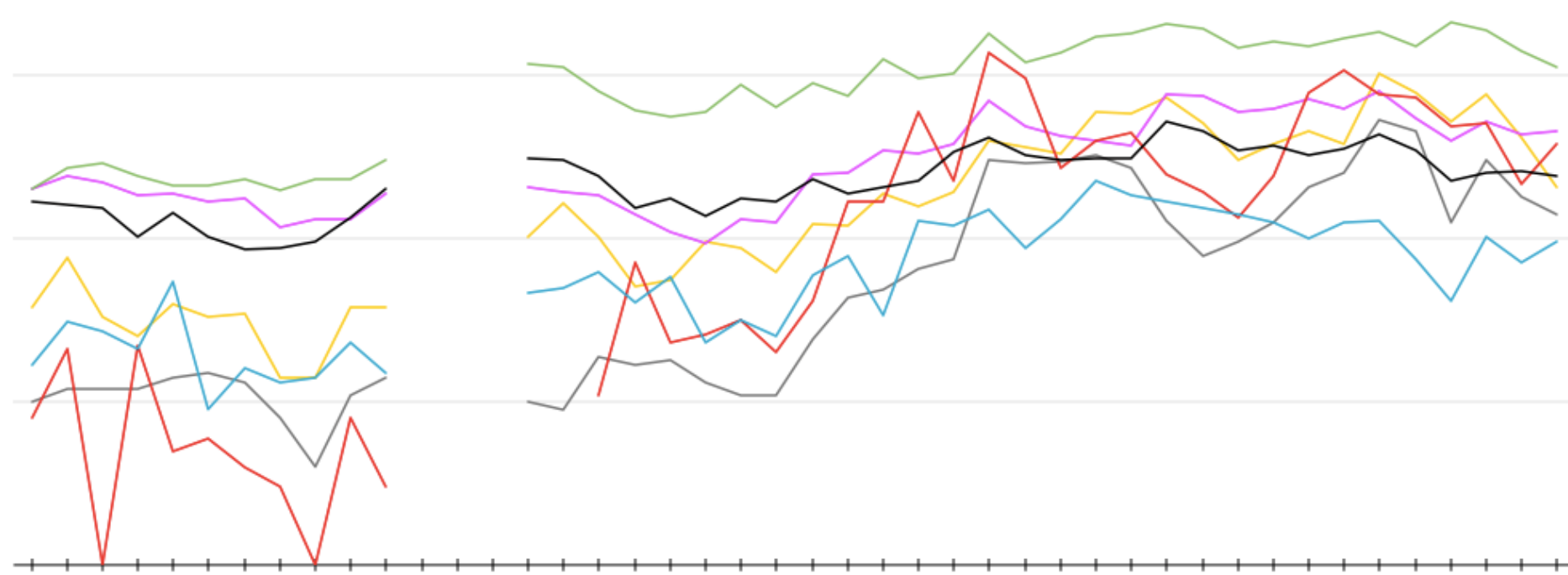

Construction Material/Yard Waste

- Furniture

- Garbage

- Haz Mat

-Tires

- Mattress

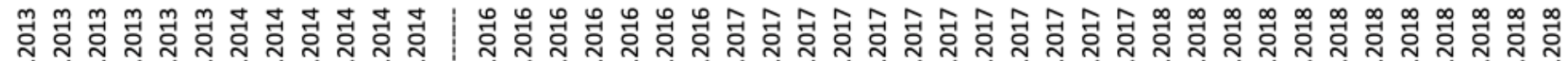

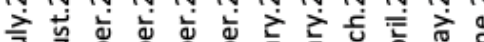

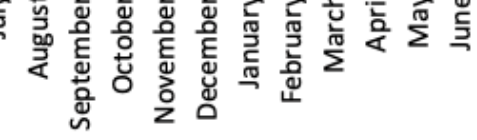

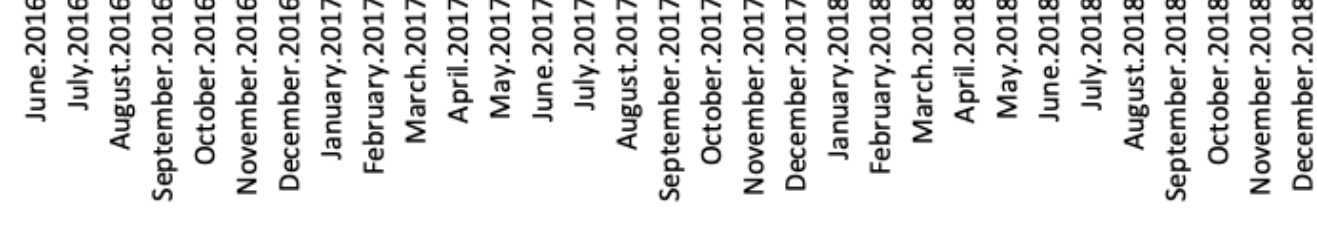


Figure 8: Linear scale of items collected by month and year

Item Count Types by Date - Linear

2500

-Appliances

2000

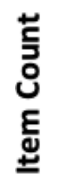

1500

1000

00

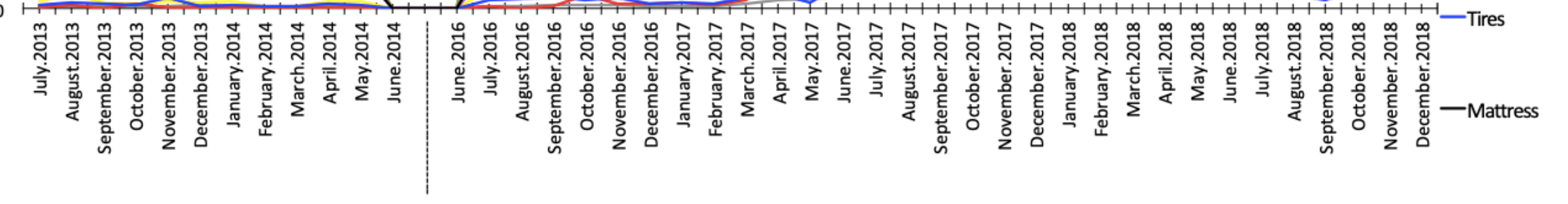

Month, Year 
Table 5 details the percent change based on the type of items picked up. The numbers highlighted indicate the significantly high increase of items picked up starting from FY 2016 to 2017 compared to FY 2017 to 2018. The data shows that the number of appliances picked up in August 2016 increased 33 times compared to August 2017. The amount of construction material/yard waste increased nine times from November 2016 to November 2017. Appliances show the highest percent change, hazmat has the second highest percent change, and construction has the third highest from FY 2016 to 2017 compared to FY 2017 to 2018. The data shows that the number of items picked up has increased in all categories. 
Table 5: Percent change of items picked up, from FY 2016-2017 to FY 2017-2018

\begin{tabular}{|c|c|c|c|c|c|c|c|c|c|c|}
\hline & July & August & September & October & November & January & February & March & April & May \\
\hline $\begin{array}{l}\text { APP - } \\
\text { Appliances }\end{array}$ & $650 \%$ & $3311 \%$ & $1411 \%$ & $1659 \%$ & $1700 \%$ & $1073 \%$ & $618 \%$ & $300 \%$ & $193 \%$ & $320 \%$ \\
\hline $\begin{array}{l}\text { CON/YW } \\
- \\
\text { Constructi } \\
\text { on } \\
\text { Material/Y } \\
\text { ard Waste }\end{array}$ & $91 \%$ & $144 \%$ & $250 \%$ & $549 \%$ & $963 \%$ & $739 \%$ & $716 \%$ & $147 \%$ & $222 \%$ & $141 \%$ \\
\hline $\begin{array}{l}\text { FUR - } \\
\text { Furniture }\end{array}$ & $80 \%$ & $266 \%$ & $167 \%$ & $201 \%$ & $262 \%$ & $479 \%$ & $497 \%$ & $142 \%$ & $144 \%$ & $107 \%$ \\
\hline $\begin{array}{l}\text { GAR - } \\
\text { Garbage }\end{array}$ & $-13 \%$ & $61 \%$ & $51 \%$ & $123 \%$ & $210 \%$ & $141 \%$ & $208 \%$ & $65 \%$ & $115 \%$ & $20 \%$ \\
\hline $\begin{array}{l}\text { HAZ - } \\
\text { HazMat }\end{array}$ & $1775 \%$ & $10000 \%$ & $8691 \%$ & $286 \%$ & $1617 \%$ & $666 \%$ & $875 \%$ & $218 \%$ & $45 \%$ & $367 \%$ \\
\hline $\begin{array}{l}\text { TIR - } \\
\text { Tires }\end{array}$ & $157 \%$ & $204 \%$ & $40 \%$ & $222 \%$ & $288 \%$ & $425 \%$ & $516 \%$ & $137 \%$ & $62 \%$ & $197 \%$ \\
\hline $\begin{array}{l}\text { MAT - } \\
\text { Mattress }\end{array}$ & $10 \%$ & $38 \%$ & $36 \%$ & $99 \%$ & $78 \%$ & $193 \%$ & $170 \%$ & $50 \%$ & $98 \%$ & $57 \%$ \\
\hline Total & $26 \%$ & $180 \%$ & $163 \%$ & $188 \%$ & $299 \%$ & $247 \%$ & $291 \%$ & $91 \%$ & $118 \%$ & $82 \%$ \\
\hline
\end{tabular}


Figure 9 shows the percent of SFD that have used the Unlimited Junk Pickup program based on data collected from FY 2017-18. The percentages for both SFDs and MFDs were calculated comparing the property addresses collected by the haulers and cross-referencing them with ESD's list of accounts and property information (Thurmon, D, personal communication, April 5, 2019). There are about 214,000 SFD units in San Jose, the data from FY 2017-18 determined that $15 \%$ of SFDs have utilized the Junk Pickup program, while $85 \%$ have not. Figure 9: Percent of single-family dwellings participated in the Junk Pickup program, FY 2017-18

\section{Single Family Dwellings Used Junk Pickup Program}

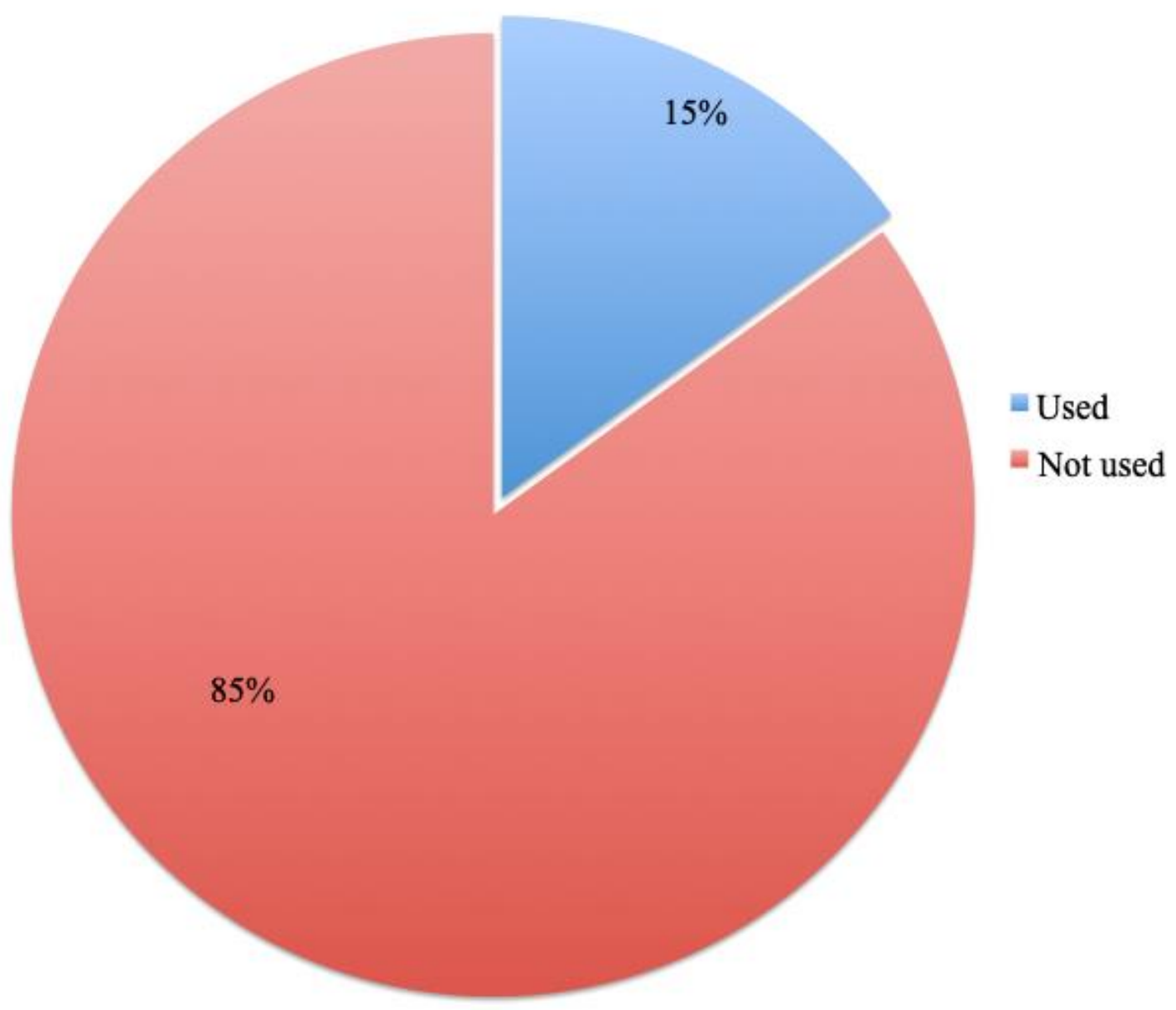


Figure 10 shows that of the 110,000 MFDs in San Jose, $50 \%$ or half of the multi-family dwelling properties have used the Junk Pickup program. The properties that participated are based on the location, not the number of units, or residents in MFDs that have used the program (Thurmon, D, personal communication, April 5, 2019).

Figure 10: Percent of multi-family dwellings participated in the Junk Pickup program, FY 2017-18

Multi Family Dwellings Used Junk Pickup Program

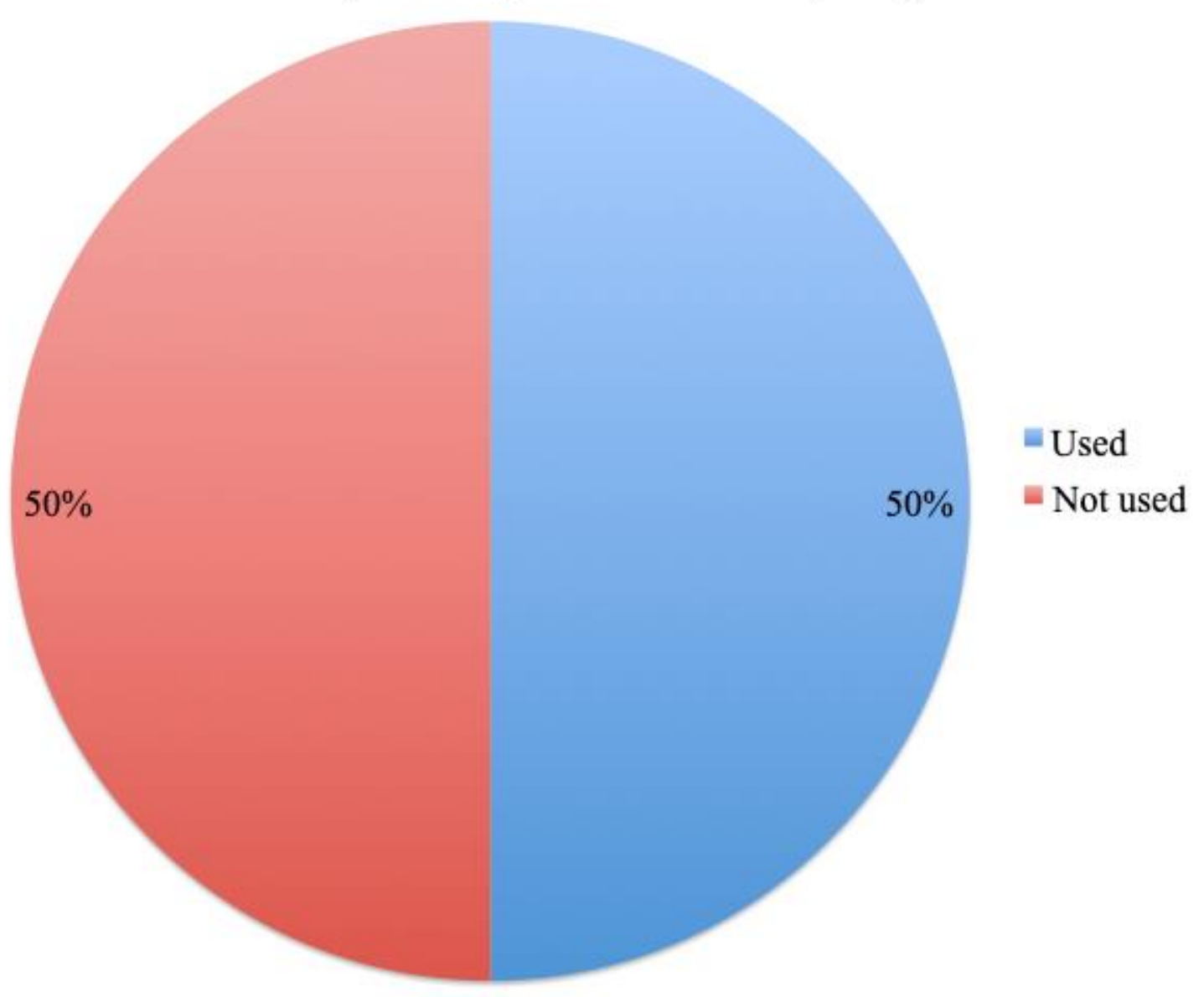




\begin{abstract}
ANALYSIS
The data collected for this research was from a relatively young program, which may not accurately demonstrate the long-term impacts of the illegal dumping program. R3 Consulting and the RAPID team may have some variations on how the data was collected, such as the data that categorized the type of items picked up, and the number of items counted during an incident. The researcher attempted to accurately count and categorize the items picked up based on the information detailed in each work order provided by R3 Consulting. One of the limitations for this research was tracking annual changes of illegal dumping based on geographic location. Prospective research could include tracking illegal dumping based on changes in geographic location. ESD can also benefit from a multi-year analysis to understand the progress of the program as other initiatives and increased outreach continue.
\end{abstract}

The first program goal in the outcome evaluation was to streamline the management of illegal dumping complaints. The RAPID program proved to achieve this goal, based on the findings that compared the change in the number of incidents each year. Increased resources, dedicated staff, and city initiatives to encourage community involvement that focused on illegal dumping may have impacted the increased number of incidents received by the program each year.

The launch of the My San Jose app also may have contributed to the $90 \%$ average increase of incidents in August 2017, which was one month after the app was publicly available. After December 2017, the number of total incidents began to overlap and slightly exceed the number of complaints received through the app. Some of the reasons that RAPID incidents eventually exceeded the number of requests by the app may be due to higher requests through phone or email, as well as RAPID staff actively picking up additional items in the field en route 
to and from an incident. Findings from the app compared to the total number of incidents indicate that the public has been actively using the app to report sightings of illegal dumping. The researcher only compared the timeframe and data from the My San Jose app based on what was provided in Moradi's 2018 research paper. Future research can continue to analyze the relationship between the My San Jose app and illegal dumping incidents received by RAPID.

Since the RAPID program was established, there have been significant increases in the number of illegal dumping incidents received by the city compared to years before. A limitation in this study was that each complaint did not specify its source, such as whether it was received via phone, email, app or picked up by a RAPID staff member en route to a reported incident. The first increase of incidents occurred at the beginning of the year in January 2017, which may be due to replacing unwanted or outdated items with new items received from the holiday season. Summer months consistently have higher incident requests, likely due to temperate climates which are associated with higher rates of outdoor activity, especially in the construction industry. Winter months also consistently have lower rates of incident requests. Missing data from March 2015 to June 2016 and January to June 2019 caused an inaccurate count of the average number of complaints by month.

One of the impacts of streamlining complaints was an increased number of incidents with no items found or picked up. There was a small jump in August 2017 of this occurrence, but became more evident in Summer 2018. There are several reasons why RAPID staff may not pick up an item from a request. One reason may be that residents may have mistaken items on the curb as illegal dumping, but they are part of the Junk Pickup Program, which requires items to be set outside 24 hours before the scheduled pickup. The RAPID team may also respond to requests quicker than haulers from the Junk Pickup Program. Other reasons include unable to locate the 
requests dumping is located on private property or out of San Jose jurisdiction, or duplicate requests. Incidents that may include material owned by the homeless are referred to the Housing Department. Dumping found on city parks is also referred to the Department of Parks, Recreation and Neighborhood Services. Future research can continue to analyze the annual differences between incidents with items collected and no items collected in order to improve how the public can report illegal dumping, and reduce incidents with no action required.

The second program goal was to decrease response time. The findings indicate that response time was longer when the program was first established, and then response time declined although incidents increased. One of the reasons for that finding is due to a backlog of incident requests causing the average response time to increase once the RAPID program began. Even though the response time was similar in 2016 compared to 2018, 2018 had significantly more incidents at 16,934, compared to 2,950 incidents in 2016. In the fiscal year 2017-2018, the RAPID program received funding for four new maintenance worker positions, which may have impacted the decrease in cleanup response times. Although the implementation of the Junk Pickup Program began in July 2017, there were no significant changes in the number of incidents received after it started. There was a steady growth of illegal dumping complaints.

The third goal focuses on programs that promote legal waste disposal rather than relying on services from the RAPID program. Many of the commonly picked up items- furniture, yard waste, mattresses, appliances, and tires -are supported by the Junk Pickup Program (Appendix A). Construction material requires a scheduled pickup from a list of authorized haulers. Hazardous waste should also be disposed of appropriately, with Santa Clara County offering free drop off locations based on the item. One of the ways garbage dumping is getting addressed includes the introduction of 500 new public litter containers that will be located throughout the 
city, which is planned for early 2019 (City of San Jose, 2019). Potential research can analyze the changes in garbage-related illegal dumping once the new public litter containers were introduced.

Information received from ESD confirmed that SFDs that used the Junk Pickup program are in more affluent council districts. The low participation rates from SFDs may be due mutiple factors such as the need for increased outreach or SFD occupants are disposing less large items. Both the Junk Pickup program and RAPID program have an increase of requests beginning in Spring to Summer (Thurmond, D, personal communication, April 5, 2019). Green Team San Jose has seen 45\% SFD user growth from FY 17-18 to FY 18-19. Green Team San Jose expects a mild growth of $10 \%$ from MFD users. There are several outreach campaigns to target hotspot areas and non-English speakers for the Junk Pickup program. Examples include a multi-faceted campaign with Univision, including a new TV commercial, partnerships with the San Jose Earthquakes and Sharks, and advertising on Pandora, Uforia (Spanish streaming internet radio), Spanish radio, Vietnamese radio, newspaper, and television. Other no-/low-cost outreach efforts that are being leveraged for high-value effects include methods such as, social media posts, Nextdoor, Civic Center TV, DMV, direct mail, and flyers at San José libraries community centers and non-profit outlets; bus shelter ads; San José Giants pocket schedule and outfield sign; Spanish and Vietnamese language websites; Council newsletters; and tabling activities at major events. Communications are conducted in multiple languages where appropriate (Thurmon, D, personal communication, April 5, 2019). 


\section{CONCLUSION}

The RAPID program appears to be adequately using the staff and the My San Jose app to address the illegal dumping incidents in San Jose. The program is fulfilling its goal of removing illegally dumped material in a timely manner. Staff is also documenting reasoning for its inability to pickup certain items when responding to an incident, and can use the data to find ways to improve incident routes throughout the city. RAPID staff must continue to collaborate with other agencies and programs in order to continue the efforts on prevention especially to SFDs and MFDs. It may be hypothesized that increased resources to respond to illegal dumping, city outreach focus on illegal dumping, and the launch of RAPID may have caused an increase of reported incidents. The RAPID program implemented many of the recommendations from R3 Consultings' analysis. Future studies should review changes in the program and the impacts on illegal dumping in San Jose. 


\section{REFERENCES}

Brandt, A. A., (2017). Illegal dumping as an indicator for community social disorganization and crime. Master's Thesis. 4835.

https://scholarworks.sjsu.edu/cgi/viewcontent.cgi?article=8382\&context=etd_theses

City of San Jose. (n.d.). Illegal dumping. Retrieved from http://www.sanjoseca.gov/illegaldumping

City of San Jose. (2017). 2017-2018 Adopted Operating Budget. Retrieved from http://www.sanjoseca.gov/DocumentCenter/View/72163

City of San Jose. (2019). Litter-ature. Retrieved on 04/04/19 from http://www.sanjoseca.gov/index.aspx?NID=6310

City of San Jose. (n.d.). Junk Pickup. Retrieved from http://www.sanjoseca.gov/junkpickup

City of San Jose Environmental Services Department. (2016). Impact analysis report. Retrieved from https://www.sanjoseca.gov/DocumentCenter/View/56473

County of Santa Clara. (2018, November 16). Household hazardous waste program. Retrieved from https://www.sccgov.org/sites/rwr/hhw/Pages/hhw.aspx

County of Santa Clara. (2018, July 26). Weekend work program rules. Retrieved from https://www.sccgov.org/sites/sheriff/Pages/wwp-rules.aspx

Dabholkar, A., Muthiyan, B., Srinivasan, S., Ravi, S., Jeon, H., \& Gao, J. (2017). Smart illegal dumping detection. 2017 IEEE Third International Conference on Big Data Computing Service and Applications (BigDataService). Retrieved from: https://ieexplore-ieeeorg.libaccess.sjlibrary.org/document/7944947

Department of Environment and Heritage Protection, Queensland, Australia. (2014). State of waste and recycling in Queensland. Retrieved from: https://www.ehp.qld.gov.au/waste/stateof-waste-report.html

Douglas, T. (1992) Pattern of land, water and air pollution by waste in managing the human impact on the natural environment: Pattern and processes. London: Belhaven Press. 
Freitas, H. \& Romanow, K. (2015 October 5). Amendments to Chapter 9.10 of Title 9 of the San Jose Municipal Code and the Administrative Citation Schedule of Fines to Address Illegal Dumping. City Council Memorandum. City of San Jose. Retrieved from http://sanjose.granicus.com/MetaViewer.php?view_id=\&event_id=1470\&meta_id=538994

Glanville, K., \& Chang, H.C. (2015). Remote sensing analysis techniques and sensor requirements to support the mapping of illegal domestic waste disposal sites in Queensland, Australia. Remote Sensing, 7, 13053-13069. doi:10.3390/rs71013053

Hammitt, J.K \& Reuter, P.H. (1988). Measuring and deterring illegal disposal of hazardous waste: A preliminary assessment. Santa Monica, CA: RAND Corporation.

Ichinose, D., \& Yamamoto, M. (2011). On the relationship between the provision of waste management service and illegal dumping. Resource and Energy Economics, 33(1), 79-93. Retrieved from: https://www-sciencedirectcom.libaccess.sjlibrary.org/science/article/pii/S0928765510000047

Kim, G.S., Chang, Y.J., \& Kelleher, D. (2008). Unit pricing of municipal solid waste and illegal dumping: an empirical analysis of Korean experience. Environmental Economics and Policy Studies, 9, 167-176.

Lanese, N. (2018, 21 January). Is San Jose winning its war on illegal dumping?. The Mercury News.

Liu, Y., Kong, F., \& Santibanez, E. (2017). Dumping, waste management and ecological security: Evidence from England. Journal of Cleaner Production. 167. 1425-1437. Retrieved from: https://www-sciencedirectcom.libaccess.sjlibrary.org/science/article/pii/S0959652616321618

Matsumoto, S., \& Takeuchi, K. (2011). The effect of community characteristics on the frequency of illegal dumping. Environmental Economics and Policy Studies, 13, 177-193. doi: 10.1007/s10018-011-0011-5

Mihai, F. C., Apostol, L., Ghiurca, A., Lamasanu, A., \& Alexandru, B. (2012). Geographical distribution of rural dumpsites in north-east region from Romania. 12th International Multidisciplinary Scientific GeoConference, SGEM Conference Proceedings, 5, 447-452.

Moradi, R. (2018). Smarter CRM from a customer service perspective: A process evaluation on the City of San Jose's My San Jose smartphone application for city services. Retrieved from: https://scholarworks.sjsu.edu/cgi/viewcontent.cgi?article=1591\&context=etd_projects 
National Association of Charitable Recycling Organisations. (2013). National waste report 2013. Retrieved from: http://www.environment.gov.au/system/files/resources/0a517ed7-74cb418b-9319-7624491e4921/files/factsheet-charitable-recycling-organisations.pdf

Nestor Resources, Inc. (2014). Illegal dumping in Pennsylvania: A decade of discovery. Retrieved from http://www.keeppabeautiful.org/Portals/0/PDFs/KPB\%20 Recommendations\%20August\%202014.pdf.

Noguchi, S. (12 August 2016). Santa Clara County opens hazardous watse drop-off site. The Mercury News. Retrieved from https://www.mercurynews.com/2014/09/13/santa-claracounty-opens-hazardous-waste-drop-off-site/

Onifade, O. A., \& Nwabotu, F.A. (2014). Implications and causes of illegal refuse dumps in Ilorin south local government area, Kwara State, Nigeria. Arabian Journal of Business and Management Review. 4(2). 148-155. Retrieved from: https://www.arabianjbmr.com/pdfs/OM_VOL_4_(2)/13.pdf

Osuntokun, A. (1999). Environmental Problem in Nigeria. Ibadan: Davidson Press. Management Review. 4(2). 148-155. Retrieved from: https://www.arabianjbmr.com/pdfs/OM_VOL_4_(2)/13.pdf

Pennsylvania Resources Council. (2017). A dozen things to know about the Covered Device Recycling Act. Retrieved from http://prc.org/12-things-about-cdra/

Porter, R.C. (2002). The Economics of Waste. Cambridge: RFF Press.

R3 Consulting Group Inc. (2015). Project report: Citywide illegal dumping analysis-final report. Murrieta, CA:MSW Consultants.

Romanow, K. \& Rios, A. Jr. (2017 a). Illegal Dumping and Litter Initiative Update. City Council Memorandum. City of San Jose. November 27. Retrieved from http://sanjose.granicus.com/MetaViewer.php?meta_id=700918

Romanow, K. \& Rios, A. Jr. (2017 b). Illegal Dumping and Litter Initiative Update. City Council Memorandum. City of San Jose. December 14. Retrieved from http://sanjose.granicus.com/MetaViewer.php?meta_id=700918 
Romanow, K. (2016). Illegal Dumping Initiative Update. City Council Memorandum. City of San Jose. November 22. Retrieved from http://sanjose.granicus.com/MetaViewer.php?meta_id=603476

Schultz, P. W., Oskamp, S., \& Mainieri, T. (1995). Who recycles and when? A review of personal and situational factors. Journal of Environmental Psychology, 15(2), 105-121.

St. Jean, P. K. B. (2007). Pockets of crime: Broken windows, collective efficacy, and the criminal point of view. Chicago, IL: University of Chicago Press.

Stark, R. (1987). Deviant places: a theory of the ecology of crime. Criminology, 25(4), 893-910.

Sylvia, R. D. \& Sylvia, K. M. (2012). Program Planning and Evaluation for the Public Manager: Fourth Edition. Long Grove, IL: Waveland Press, Inc.

Title 10 of Crimes Against the Public Health and Safety, California Penal Code $\$ 374.3$ (1872).

United States Environmental Protection Agency. (2016). Volume to weight conversion factors [Data file]. Retrieved from https://www.epa.gov/sites/production/files/201604/documents/volume_to_weight_conversion_factors_memorandum_04192016_508fnl.p df

Viazanco, A. (2017). Predictive model of illegal dumpsites in Westmoreland and York counties, Pennsylvania. Indiana University of Pennsylvania. 10642370. Retrieved from: https://search-proquest-com.libaccess.sjlibrary.org/docview/2007197377?pq-origsite=primo

White, C. (2013). Environmental impacts of homeless encampments in the Guadalupe River riparian zone. Environment and Management Thesis. MSc Thesis. Royal Roads University. Retrieved from: https://viurrspace.ca/bitstream/handle/10170/665/white_courtenay.pdf?sequence=1\&isAllo wed=y

Willis, K., Maureaud, C., Wilcox, C., \& Hardesty, B. D. (2018). How successful are waste abatement campaigns and governments policies at reducing plastic waste into the marine environment? Marine Policy. 96. 243-249.

Wright, B., Smith, L., \& Tull, F. (2018). Predictors of illegal dumping at charitable collection points. Waste Management. 74. 30-36. 


\section{Junk Pickup: Accepted Large Items}

This list may not include all large items. If you have large items not on this list, please call your recycling collection company for more information.

Note: Mixed construction and demolition debris cannot be collected through the junk pickup program. Residents may choose their own hauler from the list of non-exclusive haulers for removal. If you have items including, but not limited to, carpet, scrap lumber, or appliances, please see below for specific dimensional guidelines and set out instructions.

\begin{tabular}{|c|c|}
\hline Item & Description \\
\hline Basketball hoops & Disassembled \\
\hline Bathtub & Porcelain, cast iron (incl. Clawfoot). \\
\hline BBQ grills large & $\begin{array}{l}\text { No ashes (cold or hot). } \\
\text { № propane tanks. }\end{array}$ \\
\hline \multicolumn{2}{|l|}{ Bicycle } \\
\hline Bird bath & Ceramic or concrete. No large fountains. \\
\hline Box of items & $\begin{array}{l}\text { Total weight of box and contents not to exceed } 60 \text { pounds and } \\
\text { dimensions of box not to exceed 4'x4'x2'. No Garbage or Hazardous } \\
\text { Waste. }\end{array}$ \\
\hline Box spring & See "Mattress" \\
\hline Camper shell & $\begin{array}{l}\text { Must be a shell (not a full camper) from a passenger-sized vehicle } \\
\text { (not commercial). Shell must be no larger than } 4^{\prime} \text { wide } x 8^{\prime} \text { long and } \\
\text { no higher than cab of truck. No homemade or hardwood shells. } \\
\text { Aluminum or fiberglass shells are acceptable. }\end{array}$ \\
\hline Carpet & $\begin{array}{l}\text { Dry: Must be rolled with a length no longer than } 6^{\prime} \text { and diameter no } \\
\text { larger than 2'. } \\
\text { Wet: Must be rolled with a length no longer than } 4^{\prime} \text { and diameter no } \\
\text { larger than 2'. Carpets must be bundled or tied and manageable by } \\
\text { one person. One roll equals one item. Padding separate item. }\end{array}$ \\
\hline Chairs & $\begin{array}{l}\text { Upholstered, wood, plastic or aluminum okay. If chairs are designed } \\
\text { to stack or nest (e.g. white plastic lawn or aluminum chairs), then } 4 \\
\text { stacked chairs is } 1 \text { item. }\end{array}$ \\
\hline Compactors (trash) & Clean and empty. \\
\hline Computer & $\begin{array}{l}\text { Home computer with components (monitor, printer and CPU counts } \\
\text { as one item). }\end{array}$ \\
\hline
\end{tabular}




\begin{tabular}{|c|c|}
\hline Item & Description \\
\hline Copier & Desktop or household only. \\
\hline Counter tops & Length no longer than $8^{\prime}$; each 8 length counts as one item. \\
\hline Dishwashers & No water. \\
\hline \multicolumn{2}{|l|}{ Dog house } \\
\hline Doors (closet, front/back door) & $\begin{array}{l}\text { No all-mirrored or whole-glass doors. Small glass insert in a } \\
\text { front/back door is acceptable. }\end{array}$ \\
\hline \multicolumn{2}{|l|}{ Dresser } \\
\hline \multicolumn{2}{|l|}{ Dryer } \\
\hline Electronic Components & $\begin{array}{l}\text { Can include any or all of the following up to five items per collection: } \\
\text { Stereo receiver, turntable, two speakers, cd player, and/or VCR. }\end{array}$ \\
\hline \multicolumn{2}{|l|}{ Fax machine } \\
\hline Fences/Gate & $\begin{array}{l}\text { Length of sections must be no longer than } 8^{\prime} \text {. No more than } 60 \\
\text { pounds. Each bundle is one item. Chainlink should be rolled and } \\
\text { bundled. No entire fences, construction debris or wood/cement } \\
\text { posts. }\end{array}$ \\
\hline Fireplace inserts & No ashes (cold or hot). \\
\hline Fluorescent tubes & 6 tubes taped or tied together is 1 item \\
\hline Foam & Large foam pieces (i.e. foam packing pieces for large electronics) \\
\hline Freezer & $\begin{array}{l}\text { No longer than } 6 \text { '. Chest or upright, empty (residential type only - no } \\
\text { commercial). }\end{array}$ \\
\hline \multicolumn{2}{|l|}{ Furnace } \\
\hline Garage door opener & Disassembled and bundled. \\
\hline \multicolumn{2}{|l|}{ Garbage disposal (appliance) } \\
\hline \multicolumn{2}{|l|}{ Grandfather clock } \\
\hline Hot tub/spa & Small (2-3 person) size. No water. Deck counts as separate item(s). \\
\hline \multicolumn{2}{|l|}{ Hutch } \\
\hline Kitchen cabinets & Length no longer than $6^{\prime}$. \\
\hline \multicolumn{2}{|l|}{ Ladder } \\
\hline Large Yard Trimmings & $\begin{array}{l}\text { Oversized Yard Trimmings such as tree trunks and branches, weight } \\
\text { no greater than } 60 \text { pounds and length no longer than } 5^{\prime} \text { and }\end{array}$ \\
\hline
\end{tabular}




\begin{tabular}{|c|c|}
\hline Item & Description \\
\hline & $\begin{array}{l}\text { diameter no larger than 2', which are attributed to the normal } \\
\text { activities of a Service Unit. }\end{array}$ \\
\hline Lawn furniture & See "chairs" "picnic table" and "wood spool" sections. \\
\hline Lawn mower & Either with or without motor. No fluids. \\
\hline Light fixture & Must be placed in a box for collection. See also "box of items." \\
\hline Mattress & $\begin{array}{l}\text { Mattress and box spring are separate items. } \\
\text { King mattress and box springs ( } 2 \text { ) count as two items. }\end{array}$ \\
\hline Minibike/moped & Either with or without motor. No fluids. \\
\hline Oven & Empty. \\
\hline Pallets (wood) & $\begin{array}{l}\text { Each pallet counts as } 1 \text { item. No cement or construction and } \\
\text { demolition. }\end{array}$ \\
\hline Piano or organ & No grand pianos. Upright is acceptable and counts as three items. \\
\hline Picnic table & $\begin{array}{l}\text { Detached benches are extra items. See also "chairs" and "wood } \\
\text { spool" sections. }\end{array}$ \\
\hline Ping pong table & Folded in half. \\
\hline Plastic pools & Disassembled and bundled \\
\hline Pool cover & Prepared like carpet. \\
\hline \multicolumn{2}{|l|}{ Pool table } \\
\hline Pot belly stoves & No ashes (cold or hot). \\
\hline Refrigerators & $\begin{array}{l}\text { Empty. Doors must be removed or secured closed. Counts as one } \\
\text { item (including removed door). Residential only, no commercial } \\
\text { refrigerators. }\end{array}$ \\
\hline Shed & $\begin{array}{l}\text { Disassembled and bundled. Prefabricated only. Weight no greater } \\
\text { than } 60 \text { pounds. }\end{array}$ \\
\hline Sink & Household size, no commercial sinks. \\
\hline Sofa & If sofa is a sectional, each section counts as one item. \\
\hline Solar panels & Drained, each unit or panel is one item (like countertops). \\
\hline Spa cover & See also "hot tub/spa" section. \\
\hline Speakers & See "Electronic Components" \\
\hline Stereo & See "Electronic Components" \\
\hline
\end{tabular}




\begin{tabular}{|c|c|}
\hline Item & Description \\
\hline Stereo cabinets/hi-fi & See "Electronic Components" \\
\hline Stove & Empty. Loose items secured. \\
\hline Styrofoam & Large foam pieces (i.e. foam packing pieces for large electronics) \\
\hline Swing set & $\begin{array}{l}\text { Simple, A-frame with slide is acceptable. Jungle gyms must be } \\
\text { disassembled. Each 60-pound bundle counts as one item. }\end{array}$ \\
\hline Table saw & Household garage type, not commercial or industrial. \\
\hline Television & See "Electronic Components" \\
\hline Tables & $\begin{array}{l}\text { Table leaves may be included, but must be bundled. Each table with } \\
\text { up to three leaves counts as one item. }\end{array}$ \\
\hline Tires & $\begin{array}{l}\text { Passenger vehicle and pickup truck tires only. May have rims } \\
\text { included. One tire is one item, or one tire/rim is one item or one rim } \\
\text { separated from the tire is one item. May add } 4^{\text {th }} \text { tire for same cost. }\end{array}$ \\
\hline \multicolumn{2}{|l|}{ Toilet } \\
\hline Tree stump & $\begin{array}{l}\text { Weight no greater than } 60 \text { pounds and length no longer than } 5^{\prime} \text { and } \\
\text { diameter no larger than } 2^{\prime} \text {. }\end{array}$ \\
\hline TV & See "Electronic Components" \\
\hline VCR & See "Electronic Components" \\
\hline Vehicle body parts & $\begin{array}{l}\text { Disassembled. Items such as car door, hood, fender, car seat, and } \\
\text { camper shell. No glass windshields or engine parts. See also "tires" } \\
\text { and "camper shell" sections. }\end{array}$ \\
\hline Video arcade/pinball machines & Limited to one per household. \\
\hline Washer & Drained. \\
\hline Water bed & Drained. \\
\hline Water heater & Drained. \\
\hline \multicolumn{2}{|l|}{ Wheel barrow } \\
\hline White goods & $\begin{array}{l}\text { Inoperative or discarded refrigerators, ranges, water heaters, } \\
\text { freezers, and other similar household appliances. }\end{array}$ \\
\hline Window/door frames & Frames must be without glass. Window screens are acceptable. \\
\hline Wood scrap (scrap lumber) & $\begin{array}{l}\text { Bundled with a weight no more than } 60 \text { pounds and dimensions no } \\
\text { greater than 5'x2'x2'. Must be secured. Each bundle is one item. }\end{array}$ \\
\hline Wood spool & Small spool only, similar in size to household picnic furniture. \\
\hline
\end{tabular}


